\title{
mtDNA T8993G Mutation-Induced F1F0-ATP Synthase Defect Augments Mitochondrial Dysfunction Associated with hypoxia/reoxygenation: The Protective Role of Melatonin
}

\author{
Wen-Yi Huang ${ }^{1,20}$, Mei-Jie Jou ${ }^{3}$, I. Peng Tsung ${ }^{2,40}$ \\ 1 Graduate Institute of Clinical Medical Sciences, College of Medicine, Chang Gung University, Tao-Yuan, Taiwan, 2 Department of Neurology, Chang-Gung \\ Memorial Hospital, Keelung Branch, Taiwan, 3 Department of Physiology and Pharmacology, College of Medicine, Chang Gung University, Tao-Yuan, Taiwan, \\ 4 Department of Medicine, College of Medicine, Chang Gung University, Tao-Yuan, Taiwan
}

\begin{abstract}
Background: F1F0-ATP synthase (F1F0-ATPase) plays important roles in regulating mitochondrial function during hypoxia, but the effect of F1F0-ATPase defect on hypoxia/reoxygenation (H/RO) is unknown. The aim of this study was to investigate how mtDNA T8993G mutation (NARP)-induced inhibition of F1F0-ATPase modulates the H/ROinduced mitochondrial dysfunction. In addition, the potential for melatonin, a potent antioxidant with multiple mitochondrial protective properties, to protect NARP cells exposed to $\mathrm{H} / \mathrm{RO}$ was assessed.

Methods And Findings: NARP cybrids harboring 98\% of mtDNA T8993G genes were established as an in vitro model for cells with F1F0-ATPase defect; their parental osteosarcoma 143B cells were studied for comparison. Treating the cells with $\mathrm{H} / \mathrm{RO}$ using a hypoxic chamber resembles ischemia/reperfusion in vivo. NARP significantly enhanced apoptotic death upon H/RO detected by MTT assay and the trypan blue exclusion test of cell viability. Based on fluorescence probe-coupled laser scanning imaging microscopy, NARP significantly enhanced mitochondrial reactive oxygen species (mROS) formation and mitochondrial $\mathrm{Ca}^{2+}\left(\mathrm{mCa}^{2+}\right)$ accumulation in response to $\mathrm{H} / \mathrm{RO}$, which augmented the depletion of cardiolipin, resulting in the retardation of mitochondrial movement. With stronger $\mathrm{H} / \mathrm{RO}$ stress (either with longer reoxygenation duration, longer hypoxia duration, or administrating secondary oxidative stress following $\mathrm{H} / \mathrm{RO}$ ), NARP augmented $\mathrm{H} / \mathrm{RO}$-induced mROS formation to significantly depolarize mitochondrial membrane potential $\left(\Delta \Psi_{\mathrm{m}}\right)$, and enhance $\mathrm{mCa}^{2+}$ accumulation and nitric oxide formation. Also, NARP augmented $\mathrm{H} / \mathrm{RO}$-induced mROS oxidized and depleted cardiolipin, thereby promoting permanent mitochondrial permeability transition, retarded mitochondrial movement, and enhanced apoptosis. Melatonin markedly reduced NARP-augmented $\mathrm{H} / \mathrm{RO}$-induced mROS formation and therefore significantly reduced mROS-mediated depolarization of $\Delta \Psi \mathrm{m}$ and accumulation of $\mathrm{mCa}^{2+}$, stabilized cardiolipin, and then improved mitochondrial movement and cell survival.

Conclusion: NARP-induced inhibition of F1F0-ATPase enhances mROS formation upon H/RO, which augments the depletion of cardiolipin and retardation of mitochondrial movement. Melatonin may have the potential to rescue patients with ischemia/reperfusion insults, even those associated with NARP symptoms.
\end{abstract}

Citation: Huang W-Y, Jou M-J, Tsung IP (2013) mtDNA T8993G Mutation-Induced F1F0-ATP Synthase Defect Augments Mitochondrial Dysfunction Associated with hypoxia/reoxygenation: The Protective Role of Melatonin. PLoS ONE 8(11): e81546. doi:10.1371/journal.pone.0081546

Editor: Yidong Bai, University of Texas Health Science Center at San Antonio, United States of America

Received July 11, 2013; Accepted October 22, 2013; Published November 29, 2013

Copyright: ( 2013 Huang et al. This is an open-access article distributed under the terms of the Creative Commons Attribution License, which permits unrestricted use, distribution, and reproduction in any medium, provided the original author and source are credited.

Funding: This work was supported by the grants CMRPG 270331-3 (to Huang), CMRPG 270341-2 (to Peng), and CMRPD 180491-3 and CMRPD 170411-3 (to Jou) from the Chang Gung Memorial Hospital and Chang Gung Medical Research Foundation, Taiwan. The funders had no role in study design, data collection and analysis, decision to publish, or preparation of the manuscript.

Competing interests: The authors have declared that no competing interests exist.

*E-mail: tipeng@cgmh.org.tw

(. These authors contributed equally to this work.

\section{Introduction}

Tissue ischemia, such as acute cerebral or myocardial infarction, is characterized by severe hypoxia, acidosis, energy depletion, and cell death. Although the timely restoration of blood flow, such as infusion with tissue plasminogen activator (t-PA) or intra-arterial thrombolysis, have proven to be the most effective therapies for minimizing ischemic injury, reperfusion of ischemic tissue can result in harmful consequences [1,2]. Currently the mechanism of this hypoxia/reoxynegation (H/RO) 
injury remains uncertain. It has been shown that prolonged hypoxia damage mitochondria and inhibit the activity of electron transport chain, and proton pumping across the inner mitochondrial membrane (IMM) are inhibited, leading to ATP depletion, intracellular acidification, and $\mathrm{Ca}^{2+}$ overload [3-8]. The damaged mitochondria are no longer able to efficiently transfer electrons at reoxygenation, thereby greatly increasing reactive oxygen species (ROS) generation from complexes-I and -III [9-13]. The excessive ROS formation, $\mathrm{Ca}^{2+}$ overload and recovery of $\mathrm{pH}$ value induce the abrupt opening of the mitochondrial permeability transition pores (mPTP), which strongly contributes to cell death [14-17]. Thus excessive ROS formation in mitochondria is regarded as a crucial contributor of $\mathrm{H} / \mathrm{RO}$ injury $[1,18,19]$.

F1F0-ATP synthase (F1F0-ATPase) is the enzyme responsible for catalyzing ADP phosphorylation in oxidative phosphorylation (OXPHOS) by using the proton motive force across the IMM to drive the synthesis of ATP. To the best of our knowledge, the effect of F1F0-ATPase defect on H/RO injury has not been previously studied. Among human inherited mitochondrial disorders, the mtDNA T8993G mutation (Leu156Arg), or NARP, is well known to result in the potent inhibition of ATPase 6 of F1F0-ATPases and severe ATP deficiency [20]. Recently, our group had identified the mitochondrial characters of NARP cybrids cells (cells with $98 \%$ mtDNA T8993G mutation) in response to several apoptotic insults [21]. It has shown that NARP mutation potentiates cell apoptosis by augmenting mitochondrial ROS (mROS) formation, either in resting levels or in response to apoptotic insults $\left(\mathrm{H}_{2} \mathrm{O}_{2}\right)$. Enhanced production of mROS affects DNA, enzymes and phospholipids (e.g., cardiolipin), which results in further abnormalities in mitochondrial function and exacerbates the pathology in NARP cybrids cells [22]. In addition, the mitochondrial membrane potential $\left(\Delta \Psi_{\mathrm{m}}\right)$ of NARP cybrids cells is more hyperpolarized at rest but is more vulnerable to the oxidative insult $\left(\mathrm{H}_{2} \mathrm{O}_{2}\right)$ than that in wild-type cells [21]. This cell model provides a good opportunity to survey the influence of the F1F0-ATPase defect on H/RO injury.

Many recent publications present evidence that melatonin and several of its metabolites have significant protective actions against $\mathrm{H} / \mathrm{RO}$ injury [23-27]. Melatonin add on t-PA infusion could rescue t-PA-induced $\mathrm{H} / \mathrm{RO}$ injury in focal cerebral ischemia of mice $[28,29]$. By stabilizing cardiolipin, a unique mitochondrial protective phospholipid localized almost exclusively within the IMM, and preventing its oxidization and depletion, melatonin can rescue the retardation of mitochondrial movement, mitochondrial fission and swelling upon several apoptotic insults [21]. However, whether NARPinduced inhibition of F1F0-ATPase disrupts the protective effects by melatonin in response to $H / R O$ insults is unclear. Here we found NARP-induced inhibition of F1F0-ATPase augmented $\mathrm{H} / \mathrm{RO}$ insults-induced mROS formation, mitochondrial $\mathrm{Ca}^{2+}\left(\mathrm{mCa}^{2+}\right)$ accumulation, $\Delta \Psi_{\mathrm{m}}$ depolarization, cardiolipin depletion, and mitochondrial movement retardation, eventually increasing cell apoptosis. The administration of melatonin modulated these mitochondrial dysfunctions, and rescued either $\mathrm{H} / \mathrm{RO}$-induced or NARP-related cell apoptosis. These findings indicate important insight of the protective effect of melatonin in $\mathrm{H} / \mathrm{RO}$ injury, lighting a new neuroprotective strategy during $\mathrm{H} / \mathrm{RO}$ injury.

\section{Materials and Methods}

\section{Establishment of NARP Cybrids}

The NARP cybrids were established as described previously [30]. Briefly, skin fibroblasts obtained from a patient with Leigh's disease carrying the mtDNA T8993G mutation were enucleated and cytoplasmically fused with mtDNA-less $\left(\rho^{\circ}\right)$ human osteosarcoma 143B cells. The NARP cybrids and $\rho^{\circ}$ cells were maintained in Dulbecco's modified Eagle's medium (DMEM) containing $10 \%$ fetal bovine serum supplemented with high glucose $(4.5 \mathrm{~g} / \mathrm{mL})$, pyruvate $(0.11 \mathrm{mg} / \mathrm{mL})$, and uridine $(0.1 \mathrm{mg} / \mathrm{mL})$. NARP cybrids with a high mutant $\mathrm{mtDNA}$ to wildtype mtDNA ratio of approximately $98 \%$ were used for experiments, and comparisons were made with the parental 143B cell line. Both the NARP cybrids and 143B cells described above were kindly provided by Dr. Tanaka from Japan [48]. The cells had been used in other previous studies by our group [28,52].

\section{Hypoxia/reoxygenation Treatment to NARP Cybrids and 143B Cells}

All cell cultures were obtained by plating at low density in DMEM + 10\% FBS. All cell types were used after 48-72 $\mathrm{h}$ in culture. To induce hypoxia, cell cultures were put in a modular incubator chamber flushed with the gas mixture of $5 \% \mathrm{CO}_{2}$ and $95 \% \mathrm{~N}_{2}$ for 20 min according to the manufacturer's instructions (Billups-Rothenberg, Inc., Del Mar, CA). The deoxygenation reagent $\left(5 \% \quad \mathrm{CO}_{2}\right.$ and $<1 \% \quad \mathrm{O}_{2}$; Mitsubishi Gas Chemical, Tokyo, Japan) was placed inside the chamber. Next, the sealed chamber was placed into a $37^{\circ} \mathrm{C}$ incubator. The chamber was incubated for different hypoxic durations $(6,12$, and $18 \mathrm{~h}$ ). After hypoxia incubation, the cells were washed with normoxic culture medium twice, and then transferred to their respective normal culture medium and restored to the $37^{\circ} \mathrm{C}$ incubator with $5 \% \mathrm{CO}_{2}$ for reoxygenation $(1,2,3$, and $4 \mathrm{~h}$ ). As reoxygenation after hypoxia results in overproduction of mROS, a secondary oxidative stress $\left(5 \mathrm{mM} \mathrm{H}_{2} \mathrm{O}_{2}\right)$ was administered following $\mathrm{H} / \mathrm{RO}$ treatment in some experiments for augmenting and accelerating the effect of $\mathrm{H} / \mathrm{RO}$ insults. For melatonin treatment during $\mathrm{H} / \mathrm{RO}$ treatment, $100 \mu \mathrm{m}$ melatonin (Sigma Aldrich, St. Louis, MO) was added to all media and buffers during the whole procedure of $\mathrm{H} / \mathrm{RO}$ treatment and 100 $\mu \mathrm{m}$ melatonin was also added in $5 \mathrm{mM} \mathrm{H}_{2} \mathrm{O}_{2}$ if used. For supplemental data, mitochondria-specific antioxidant MitoQ $(0.2 \mathrm{nM})$ or general antioxidant vitamin $\mathrm{E}(200 \mu \mathrm{m})$ was added to all media and buffers during the whole procedure of $\mathrm{H}_{2} \mathrm{O}_{2}$ augmented $\mathrm{H} / \mathrm{RO}$ treatment.

\section{Measurement of Cell Viability}

Cell viability was detected by using the colorimetric $3-(4,5-$ dimethyl-2-thiazolyl)-2,5-diphenyl-2H-tetrazolium bromide (MTT) assay as previously described [31]. The activity of the mitochondrial reductase to convert a soluble tetrazolium salt into an insoluble formazan precipitate was measured using an 
enzyme-linked immunoabsorbent assay (ELISA) reader (A-5082; TECAN, Grödig/Salzburg, Austria). The MTT assay was performed $1 \mathrm{~h}$ after stress exposure. The activity of the mitochondrial reductase was calculated as the amount of MTT dye conversion in treated cells relative to that of sham-treated control cells. Data are represented as the means \pm standard error (SE) of at least three independent experiments. In addition, we used the trypan blue exclusion test of cell viability as previously described to measure cell viability in response to $\mathrm{H} / \mathrm{RO}$ treatment [32].

\section{Apoptotic Cell Analysis}

The flip-flop of phosphatidylserine (PS) from the inner- to the outer-plasma-membrane leaflet is a common phenomenon in apoptosis. The exposure of PS is an early event that precedes cell shrinkage and nuclear condensation. PS exposure induced by $\mathrm{H} / \mathrm{R}$ in cells was detected by FITC-conjugated Annexin VFITC staining [33]. This is observed as green fluorescence on the plasma membrane during the occurrence of PS externalization. The precise time point for PS exposure and cell death were carefully detected by the imaging of cells duallabeled with Annexin V-FITC and propidium iodide (PI) after they were exposed to $\mathrm{H} / \mathrm{RO}$ treatment using fluorescence microscopy.

\section{Immunocytochemical Analysis for Detecting Cytochrome c Release from Mitochondria into the Cytosol after Hypoxia/Reoxygenation}

Apoptotic events were identified by cytochrome $c$ distribution after H/RO. Cells were grown on \#1 glass cover slips for $48 \mathrm{~h}$ in DMEM containing $10 \%$ fetal bovine serum supplemented with high glucose $(4.5 \mathrm{~g} / \mathrm{mL})$, pyruvate $(0.11 \mathrm{mg} / \mathrm{mL})$, and uridine $(0.1 \mathrm{mg} / \mathrm{mL})$. After $\mathrm{H} / \mathrm{RO}$, cells were rinsed with phosphate buffered saline (PBS), and then fixed in $3.7 \%$ paraformaldehyde for $15 \mathrm{~min}$ at room temperature (RT). After fixation, the cover slips were rinsed in PBS and placed in $0.1 \%$ Triton X-100 for $10 \mathrm{~min}$ at RT. The cells were then washed with PBS and incubated with $1 \%$ bovine serum albumin (BSA) for 1 h. For immunostaining of mitochondrial complex II and cytochrome $c$, glass cover slips were incubated with primary antibodies (mouse) diluted 1:100 in PBST for $1 \mathrm{~h}$ at RT, and then the cover slips were washed 3 times for 5 min each in PBS. Cover slips were first incubated with a secondary antibody, tetramethyl rhodamine rabbit anti-mouse antibody (Acris antibody) diluted at 1:1000 in phosphate buffered saline (PBS) for $60 \mathrm{~min}$ at RT, and then, the cover slips were further incubated for $1 \mathrm{~h}$ at RT. After the cover slips were washed 3 times, they were incubated with another primary antibody (rabbit) diluted at 1:100 in PBS-Tween (PBST) for $1 \mathrm{~h}$ at RT. Then the cover slips were washed 3 times for 5 min each in PBS. The cover slips were then exposed for $60 \mathrm{~min}$ at RT to an Alexa fluor $^{\circledR} 488$ conjugated goat anti-rabbit $\lg (\mathrm{H}+\mathrm{L})$ secondary antibody (Abcam, Cambridge, MA, USA) diluted 1:1000. The cover slips were washed 3 times for 5 min in PBS and then incubated for 1 min with PBS containing Hoechst $33342(1 \mu \mathrm{g} / \mathrm{mL}$ ), and then washed with PBS (3 washes $5 \mathrm{~min}$ each) before mounting for observation. The fluorescence intensity of complex expression was observed under a Zeiss inverted microscope.

\section{Cell Preparation for Imaging}

For imaging detection, cells were grown in medium consisting of DMEM containing $10 \%$ fetal bovine serum supplemented with high glucose $(4.5 \mathrm{~g} / \mathrm{mL})$, pyruvate $(0.11 \mathrm{mg} /$ $\mathrm{mL})$, and uridine $(0.1 \mathrm{mg} / \mathrm{mL})$. All cells were plated onto \#1 glass cover slips for fluorescent microscopy.

\section{Chemical and Fluorescent Dye Loading for Fluorescence Measurement of Mitochondrial Events}

All chemicals were obtained from Sigma-Aldrich and fluorescent dyes were purchased from Molecular Probes Inc. (Eugene, OR, USA). Loading conditions for each specific fluorescent probe are described as follows: $\Delta \Psi_{\mathrm{m}}$ was detected using $200 \mathrm{nM}$ tetramethylrhodamine methyl ester (TMRM); $\mathrm{mCa}^{2+}$ was detected using $2 \mu \mathrm{M}$ Rhod-2 AM (Rhod-2); ROS was detected using $2 \mu \mathrm{M}$ 6-carboxy-2',7'dichlorodihydrofluorescein diacetate (DCFH-DA); nitric oxide (NO) was detected using $5 \mu \mathrm{M}$ 4-amino-5-methylamino-2',7'difluorofluorescein diacetate (DAF-FM); and cardiolipin was detected using $80 \mathrm{nM}$ nonyl acridine orange (NAO). All fluorescent probes were loaded at RT for 30 min except TMRM, which was loaded for $10 \mathrm{~min}$ to prevent quenching. After loading, cells were rinsed 3 times with HEPES-buffered saline solution (containing $140 \mathrm{mM} \mathrm{NaCl}, 5.4 \mathrm{mM} \mathrm{KCl}, 1.8 \mathrm{mM}$ $\mathrm{CaCl}_{2}, 0.8 \mathrm{mM} \mathrm{MgCl}, 10 \mathrm{mM}$ glucose, $10 \mathrm{mM}$ HEPES; $\mathrm{pH}$ 7.4). Cells loaded with the ester form of dyes including DCFHDA and Rhod-2 required an additional 30-40 min of incubation after dye loading to allow intracellular deacetylation of the dye. Dye-loaded cells were then mounted on a cell chamber for conventional or laser-coupled imaging microscopic observation.

\section{Imaging Analysis of Living Cells}

Confocal fluorescence images and image stacks were collected using a Zeiss LSM 510 META NLO mounted on an Axiovert $200 \mathrm{M}$ inverted microscope (Carl Zeiss Microimaging, Inc., Thornwood, NY). All fluorescence images were collected using a Zeiss objective lens (Plan-Apochromat 100X, NA1.4 oil DIC M27). NAO was excited using the Argon/2 laser (30 mW) for excitation. The excitation wavelength was $488 \mathrm{~nm}$, the main dichroic beam splitter was 488/561 nm, and the emission detection filter was band pass $500-550 \mathrm{~nm}$.

All images were processed and analyzed using MetaMorph software (Universal Imaging Corp., West Chester, PA, USA). Intensity levels were analyzed from the original images and graphed using Microsoft Excel software and Photoshop. For analyzing $\mathrm{mROS}$ and mitochondrial $\mathrm{NO}$ ( $\mathrm{mNO}$ ) fluorescent intensity, we selected and measured the regions overlapping with DCFH-DA (to measure ROS) and TMRM (to measure $\Delta \Psi_{\mathrm{m}}$ ) signals, DAF-FM (to measure NO) and TMRM signals, respectively. Therefore, we were able to make sure that the regions we analyzed were mitochondrial regions. For analyzing fluorescent intensity of cardiolipin, we selected and measured the region overlapping with NAO (to measure cardiolipin) and Rhod-2 (to measure $\mathrm{mCa}^{2+}$ ) to confirm that the sites we 
measured were mitochondrial regions. To take into account the initial influence of $\Delta \Psi_{\mathrm{m}}$ on $\mathrm{NAO}$, we calculated the percentage of fluorescent intensity of NAO signals [100-(The control fluorescent intensity of NAO in mitochondria-the recording fluorescent intensity of NAO in mitochondria) / The control fluorescent intensity of NAO in mitochondria $\times 100] \%$.

\section{Treatment Protocols of Confocal Experiments on H/RO}

To evaluate the effect of hypoxia for $6 \mathrm{~h}$ with different reoxygenation durations $(1,2,3$, and $4 \mathrm{~h})$ on different mitochondrial parameters, the cells ( $n \geq 6$ dishes/group) were treated as follows:

1. Control: cells were stained with different mitochondrial fluorescent dyes for $30 \mathrm{~min}$, and then visualized under a confocal microscope. We double stained cells with $200 \mathrm{nM}$ TMRM and $2 \mu \mathrm{M}$ DCFH-DA, $200 \mathrm{nM}$ TMRM and $5 \mu \mathrm{M}$ DAF-FM, or $80 \mathrm{nM} \mathrm{NAO}$ and $2 \mu \mathrm{M}$ Rhod-2 in order to localize the mitochondria and compare different mitochondrial parameter at the same time.

2. Hypoxia for $6 \mathrm{~h}$ followed by reoxygenation for $1,2,3$, and $4 \mathrm{~h}$ : cells were subjected to hypoxia for $6 \mathrm{~h}$ followed by reoxygenation for $30 \mathrm{~min}, 1 \mathrm{~h} 30 \mathrm{~min}, 2 \mathrm{~h} 30 \mathrm{~min}$, and 3 h $30 \mathrm{~min}$, respectively. Then cells were stained and visualized as control (1).

To evaluate the effect of different hypoxic durations $(6,12$, and $18 \mathrm{~h}$ ) with the same time of reoxygenation (2h) on cardiolipin depletion and $\mathrm{mCa}^{2+}$ accumulation, the cells $(\mathrm{n} \geq 6$ dishes/group) were treated as follows:

1. Control: cells were double stained with $80 \mathrm{nM}$ NAO and $2 \mu \mathrm{M}$ Rhod-2 for $30 \mathrm{~min}$, and then visualized at every 3 $\min$ for $1 \mathrm{~h}$.

2. Hypoxia for 6,12 , and $18 \mathrm{~h}$ followed by reoxygenation for $2 \mathrm{~h}$ : cells were subjected to hypoxia for 6,12 , and $18 \mathrm{~h}$; followed by reoxygenation for $1 \mathrm{~h} 30 \mathrm{~min}$, then stained and visualized as control (1).

To evaluate the effect of $\mathrm{H}_{2} \mathrm{O}_{2}$-augmented $\mathrm{H} / \mathrm{RO}$ (hypoxia: 6 $\mathrm{h}$; reoxygenation: $2 \mathrm{~h}$ ) on $\mathrm{mROS}$, cardiolipin, $\Delta \Psi \mathrm{m}$ and $\mathrm{mCa}^{2+}$ and the protective effects of melatonin treatment, the cells $(n \geq$ 6 dishes/group) were treated as follows:

1. Control: cells were stained with $2 \mu \mathrm{M} \mathrm{DCFH-DA}$ and 200 $\mathrm{nM}$ TMRM, or $80 \mathrm{nM}$ NAO and $2 \mu \mathrm{M}$ Rhod-2 for $30 \mathrm{~min}$, then $5 \mathrm{mM} \mathrm{H}_{2} \mathrm{O}_{2}$ was added and visualized at every $1 \mathrm{~min}$ for 30 min under a confocal microscope.

2. $\mathrm{H}_{2} \mathrm{O}_{2}$-augmented $\mathrm{H} / \mathrm{RO}$ treatment $(\mathrm{H}: 6 \mathrm{~h}$; RO: $2 \mathrm{~h})$ : cells were subjected to hypoxia for $6 \mathrm{~h}$ and reoxygenation for $1 \mathrm{~h}$ and $30 \mathrm{~min}$, then stained and visualized as control (1).

3. Adding $100 \mu \mathrm{m}$ melatonin during the $\mathrm{H}_{2} \mathrm{O}_{2}$-augmented $\mathrm{H} / \mathrm{RO}(\mathrm{H}: 6 \mathrm{~h}$; RO: $2 \mathrm{~h}$ ): During the whole procedure of $\mathrm{H}_{2} \mathrm{O}_{2}$-augmented $\mathrm{H} / \mathrm{RO}$ treatment, $100 \mu \mathrm{m}$ melatonin was added to all media and buffers.

\section{Measurement of Mitochondrial Movement}

Mitochondrial movement was continuously time-lapse imaged using a mitochondria-targeted fluorescent probe (either
$80 \mathrm{nM}$ cardiolipin or $200 \mathrm{nM}$ TMRM) before and after the cells received $\mathrm{H} / \mathrm{RO}$ treatment. Mitochondrial movement was measured from the overlapping mitochondrial area (in yellow; i.e., nonmoving area) of a superimposed image of 2 consecutive images (the first image labeled the mitochondrial area red in color and the second image labeled the mitochondrial area green in color) taken $2 \mathrm{~min}$ apart. The percentage of the overlapping mitochondrial area of the 2 images (in yellow; i.e., nonmoving area) to total mitochondrial area (counted from the total mitochondrial area of the first image) was designated the overlapping percentage. If the mitochondrial movement became retarded, the overlapping percentage increased (yellow area increased). If the mitochondrial movement accelerated, the overlapping percentage decreased (yellow area decreased). The average of 10 representative populations of mitochondria in one single cell from 10-20 cells was calculated [21].

\section{Statistical Analysis}

Results are expressed as mean \pm standard error of the mean (SEM) and statistical significance was evaluated by either oneway or multi-factorial analysis of variance (ANOVA). A P value less than 0.05 was considered statistically significant. Each experiment was repeated at least 3 times.

\section{Results}

\section{NARP Augments H/RO-induced Apoptosis}

The effects of NARP-induced inhibition of F1F0-ATPase on cell survival in response to $\mathrm{H} / \mathrm{RO}(\mathrm{H}: 6 \mathrm{~h}$; $\mathrm{RO}: 2 \mathrm{~h})$ stress were detected using Annexin V-PI staining, immuoncytochemical analysis, MTT assays, and the trypan blue exclusion test of cell viability. After $\mathrm{H} / \mathrm{RO}$ treatment, NARP cybrids showed marked cell death as measured by Annexin V-PI staining (Figure 1A). As shown in Figure 1B, cytochrome $\mathrm{c}$ (green fluorescent signal) released from the mitochondria (yellow region) into the cytosol was detected by immunocytochemical analysis in both NARP cybrids and 143B cells in response to H/RO insults. The result of MTT assay demonstrated that NARP-induced inhibition of F1F0-ATPase resulted in more severe apoptotic death in response to $\mathrm{H} / \mathrm{RO}$ insults as compared with the parental $143 \mathrm{~B}$ cells (survival rate: $143 \mathrm{~B}[82 \pm 3.2 \%]>\mathrm{NARP}[58 \pm 2.1 \%]$, $P<0.05$ ) (Figure $1 \mathrm{C}$ ). The result of the trypan blue exclusion test also showed that NARP-induced inhibition of F1F0ATPase resulted in more severe cell death in response to $\mathrm{H} / \mathrm{RO}$ insults as compared with the parental 143B cells (cell death rate: $143 \mathrm{~B}[27 \pm 4.1 \%]<\mathrm{NARP}[56 \pm 6.3 \%], P<0.05$ ) (Figure 1D). Based on these results, we found that $H / R O$ insults led to apoptotic death in both NARP cybrids and 143B cells. Besides, the NARP-induced inhibition of F1F0-ATPase augmented H/RO-induced apoptosis in comparison to $143 \mathrm{~B}$ cells. 


\section{A NARP (Annexin V / PI)}

Control

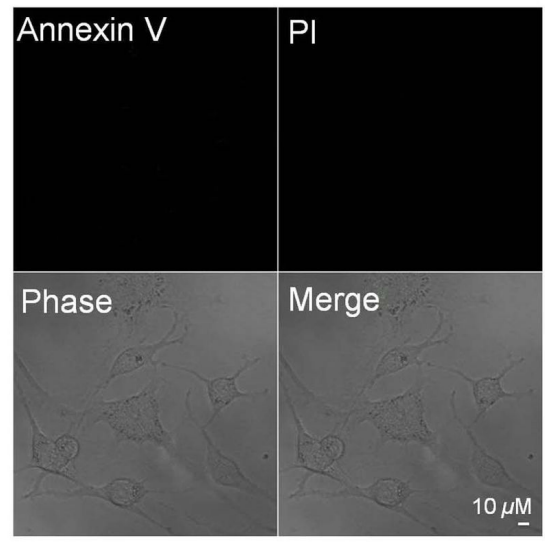

H6h/RO2h

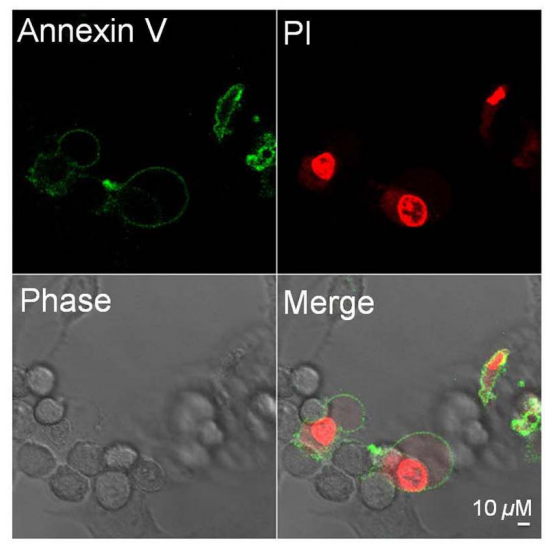

B

\section{Control}

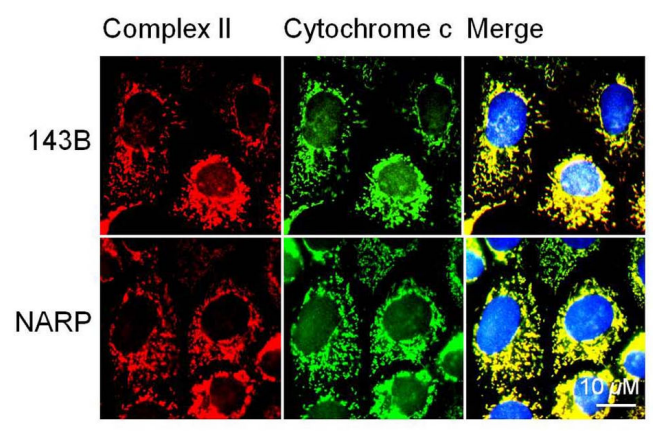

C

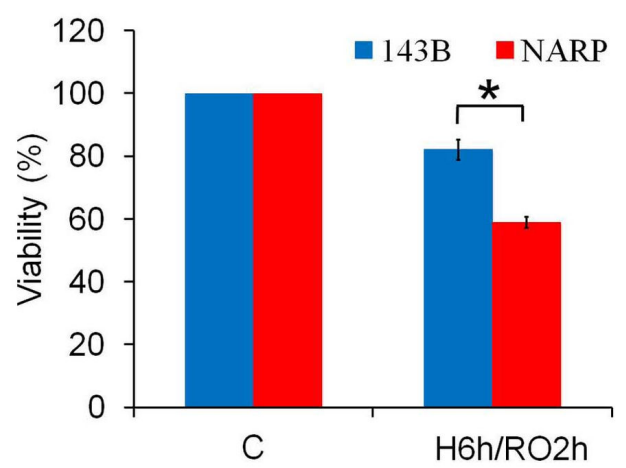

\section{H6h/RO2h}

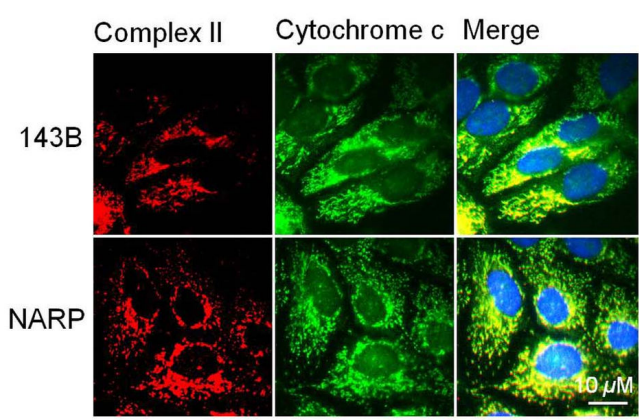

D

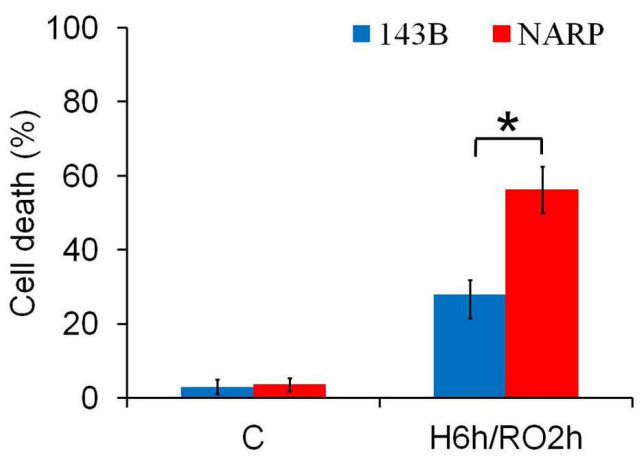

Figure 1. Hypoxia/reoxygenation (H/RO) induced apoptotic death in NARP cybrids and 143B cells. (A) $H / R O(H: 6 h, R O: 2 h)$ induced apoptosis in NARP cybrids as measured by Annexin V-propidium iodide (PI) staining. (B) H/RO induced cytochrome $\mathrm{C}$ release from mitochondria in NARP cybrids and 143B cells as measured by immunocytochemical analysis. Red color: mitochondrial complex II; Green color: cytochrome c. Note that cytochdrome c and complex II co-localized well before H/RO (yellow color). After $\mathrm{H} / \mathrm{RO}$, green fluorescent signal was released from mitochondria in NARP cybrids and 143B cells, which suggested that cytochdrome $\mathrm{c}$ was released from mitochondria. (C) MTT assay. After H/RO, cell death was noted in NARP cybrids and 143B cells (death ratio: NARP > 143B). (D) Trypan blue exclusion test of cell viability. After H/RO, cell death was noted in NARP cybrids and 143B cells (death ratio: NARP $>143 \mathrm{~B}$ ). ${ }^{*} P<0.05$ as compared with control; $n=3$.

doi: 10.1371/journal.pone.0081546.g001 


\section{NARP Augments H/RO (with the same duration of hypoxia and different durations of reoxygenation)- induced Mitochondrial Dysfunction}

Next, we investigated how NARP-induced inhibition of F1F0ATPase augmented H/RO treatment-induced apoptosis. Resting levels of $\Delta \Psi \mathrm{m}, \mathrm{mROS}, \mathrm{mNO}$, cardiolipin and $\mathrm{mCa}^{2+}$ were simultaneously imaged using $200 \mathrm{nM}$ TMRM, $2 \mu \mathrm{m}$ DCFH-DA, $5 \mu \mathrm{m}$ DAF-FM, $80 \mathrm{nM}$ NAO and $2 \mu \mathrm{m}$ Rhod-2, respectively, before and after $\mathrm{H} / \mathrm{RO}$ treatment in NARP cybrids and $143 \mathrm{~B}$ cells. We used the same duration of hypoxia $(6 \mathrm{~h})$ and different durations of reoxygenation $(1,2,3$, and $4 \mathrm{~h}$ ) to simulate dose-dependent $\mathrm{H} / \mathrm{RO}$ insults. As shown in Figure 2A and $2 A^{\prime}$, NARP resulted in hyperpolarized $\Delta \Psi_{\mathrm{m}}$ as compared with the parental 143B cells before $\mathrm{H} / \mathrm{RO}$ treatment $(P<0.05)$, which was similar to what we observed in our previous study [21]. The $\Delta \Psi_{\mathrm{m}}$ in NARP cybrids, although more hyperpolarized before $\mathrm{H} / \mathrm{RO}$ treatment, were depolarized much more severely than $\Delta \Psi_{\mathrm{m}}$ in $143 \mathrm{~B}$ cells after $\mathrm{H} / \mathrm{RO}$ treatment with longer reoxygenation durations $(2-4 \mathrm{~h})\left(\Delta \Psi_{\mathrm{m}}\right.$ of NARP $<\Delta \Psi_{\mathrm{m}}$ of 143B when reoxygenation durations were 2-4 $\mathrm{h}, P<0.05)$, suggesting NARP-induced hyperpolarization of $\Delta \Psi_{\mathrm{m}}$ was vulnerable to the $\mathrm{H} / \mathrm{RO}$ insult, which was similar to what we noted in our previous study with other apoptotic insults [21]. Figure 2B and 2B' showed that NARP augmented dosedependent $\mathrm{H} / \mathrm{RO}$ insults-induced mROS formation (mROS of NARP $>$ mROS of 143B when reoxygenation duration was 3-4 $\mathrm{h}, \quad P<0.05)$. In NARP cybrids, higher levels of mROS associated with more severe depolarization of $\Delta \Psi_{\mathrm{m}}$ suggested that NARP-induced inhibition of F1F0-ATPase augmented mROS (induced by $\mathrm{H} / \mathrm{RO}$ insult)-induced $\Delta \Psi \mathrm{m}$ depolarization.

Furthermore, we investigated how $\mathrm{H} / \mathrm{RO}$ insults-induced mROS formation altered cardiolipin content, a critical mitochondrial protective phosphopholipid and the levels of $\mathrm{mCa}^{2+}$, another potent mitochondrial stress that activates the opening of mPTP. Resting levels of cardiolipin and $\mathrm{mCa}^{2+}$ were simultaneously imaged using $80 \mathrm{nM} \mathrm{NAO}$ and $2 \mu \mathrm{m}$ rhod-2, respectively, before and after $\mathrm{H} / \mathrm{RO}$ treatment $(\mathrm{H}$ : $6 \mathrm{~h}$; $\mathrm{RO}$ : 1-4 h) in NARP cybrids and 143B cells. Compared with 143B cells, the resting level of $\mathrm{mCa}^{2+}$ in NARP cybrids was higher, which was due possibly to the inhibition of F1F0-ATPase-induced hyperpolarization of $\Delta \Psi \mathrm{m}(P<0.05)$ (Figure $2 \mathrm{E}$ and $2 \mathrm{E}$ '). After $\mathrm{H} / \mathrm{RO}$ treatment, dose dependency of $\mathrm{H} / \mathrm{RO}$ insult-induced $\mathrm{mCa}^{2+}$ accumulation was noted in both $143 \mathrm{~B}$ cells and NARP cybrids, NARP augmented this effect significantly $\left(\mathrm{mCa}^{2+}\right.$ of NARP $>\mathrm{mCa}^{2+}$ of $143 \mathrm{~B}$ when reoxygenation duration was 1-3 h, $P<0.05$ ) (Figure 2E and 2E'). Figure 2D and 2D' showed that NARP-induced inhibition of F1F0-ATPase augmented the depletion of cardiolipin in response to $\mathrm{H} / \mathrm{RO}$ insult (RO: $4 \mathrm{~h}$ ) $(>50 \%, P<0.05)$. Interestingly, the event of cardiolipin depletion happened later (longer duration of reoxygenation) than $\Delta \Psi_{\mathrm{m}}$ depolarization, $\mathrm{mROS}$ formation and $\mathrm{mCa}^{2+}$ accumulation, suggesting that NARP-induced inhibition of F1F0-ATPase augmented $\mathrm{mROS}$ (induced by $\mathrm{H} / \mathrm{RO}$ insult)-induced $\Delta \Psi \mathrm{m}$ depolarization and $\mathrm{mCa}^{2+}$ accumulation, which resulted in the depletion of cardiolipin, the opening of MPTP, and eventually cell death. We also observed that NARP augmented $\mathrm{mNO}$ formation as compared with $143 \mathrm{~B}$ cells in response to dose- dependent $\mathrm{H} / \mathrm{RO}$ treatment (Figure $2 \mathrm{C}$ and $2 \mathrm{C}^{\prime}$ ), which may also contribute to $\mathrm{H} / \mathrm{RO}$ insult-induced cell death.

\section{NARP Augments Longer Duration of Hypoxia (with the Same Duration of Reoxygenation)-induced Cardiolipin Depletion and $\mathrm{mCa}^{2+}$ Accumulation}

Due to the depletion of cardiolipin occurring later than mROS formation, $\Delta \Psi_{\mathrm{m}}$ depolarization and $\mathrm{mCa}^{2+}$ accumulation in response to $\mathrm{H} / \mathrm{RO}$ treatment, we next investigated the effects of longer duration of hypoxia (with the same duration of reoxygenation) on cardiolipin content in NARP cybrids and 143B cells. After $\mathrm{H} / \mathrm{RO}$ treatment $(\mathrm{H}: 0,6,12$, and $18 \mathrm{~h}$; RO: 2 h), cells were stained with $80 \mathrm{nM} N A O$ (to measure cardiolipin) and $2 \mu \mathrm{m}$ Rhod-2 (to measure $\mathrm{mCa}^{2+}$ ). Then the cell images were recorded by confocal microscopy at every $3 \mathrm{~min}$ to monitor the resting change of cardiolipin content and $\mathrm{mCa}^{2+}$. Interestingly, depletion of cardiolipin was noted gradually after $\mathrm{H} / \mathrm{RO}$ treatment $(\mathrm{H}: 12$ and $18 \mathrm{~h}$; RO: $2 \mathrm{~h})$ in NARP cybrids $(P<0.05$, at $42 \mathrm{~min}$ and $60 \mathrm{~min})$ but not in 143B cells (Figure S1A-B; Figure 3A, $\left.A^{\prime}, B, B^{\prime}\right)$. In addition, marked and persistent accumulation of $\mathrm{mCa}^{2+}$ was noted after $\mathrm{H} / \mathrm{RO}$ treatment in NARP cybrids but not in 143B cells exposed to hypoxia for $18 \mathrm{~h}$ $(P<0.05, \mathrm{H} 1 \mathrm{~h}$ group compared with control group) (Figure S1D; Figure 3D, D'). Only a small amount and transient accumulation of $\mathrm{mCa}^{2+}$ was noted in $143 \mathrm{~B}$ cells (Figure S1C; Figure $3 \mathrm{C}, \mathrm{C}^{\prime}$ ). Furthermore, the mitochondrial morphology of $143 \mathrm{~B}$ cells remained thread-like when receiving $\mathrm{H} / \mathrm{RO}$ treatment with hypoxia for 12 and $18 \mathrm{~h}$ (Figure 3A). However, the mitochondrial morphology of NARP cybrids was characterized by swelling and roundness when receiving $\mathrm{H} / \mathrm{RO}$ treatment with hypoxia for 12 and $18 \mathrm{~h}$ (Figure 3B). These results, thus, indicate that the NARP cybrids were more sensitive to longer hypoxic duration (with the same duration of reoxygenation)induced cardiolipin depletion and of $\mathrm{mCa}^{2+}$ accumulation. Our previous study had suggested that cardiolipin possibly plays a central role in regulating mitochondrial dynamics that is associated with NARP-augmented pathology and is crucial for maintaining normal mitochondrial movement [21]. Therefore, we proposed that the NARP-enhanced depletion of cardiolipin in response to $\mathrm{H} / \mathrm{RO}$ insults may lead to more severe retardation of mitochondrial movement in comparison to $143 \mathrm{~B}$ cells.

\section{NARP Augments H/RO-induced Retardation of Mitochondrial Movement}

We next investigated whether NARP augmented the retardation of mitochondrial movement in response to $H / R O$ treatment $(\mathrm{H}: 0,6,12$, and $18 \mathrm{~h}$; RO: $2 \mathrm{~h})$. We loaded the cells with $80 \mathrm{nM} \mathrm{NAO}$, and mitochondrial movement was analyzed using time-lapse imaging continuously in 143B cells and NARP cybrids. Before $\mathrm{H} / \mathrm{RO}$ treatment, the NARP cybrids did not show significantly reduced mitochondrial movement compared with the $143 \mathrm{~B}$ cells, so that the non-moving mitochondrial population analyzed from the percentage of the overlapping area (yellow area) of two consecutive images (the first image labeled red in color and the second image labeled green in color, taken $2 \mathrm{~min}$ apart) to total mitochondrial area (mitochondrial area in the first image) was $45 \pm 3.2 \%$ in $143 \mathrm{~B}$ 

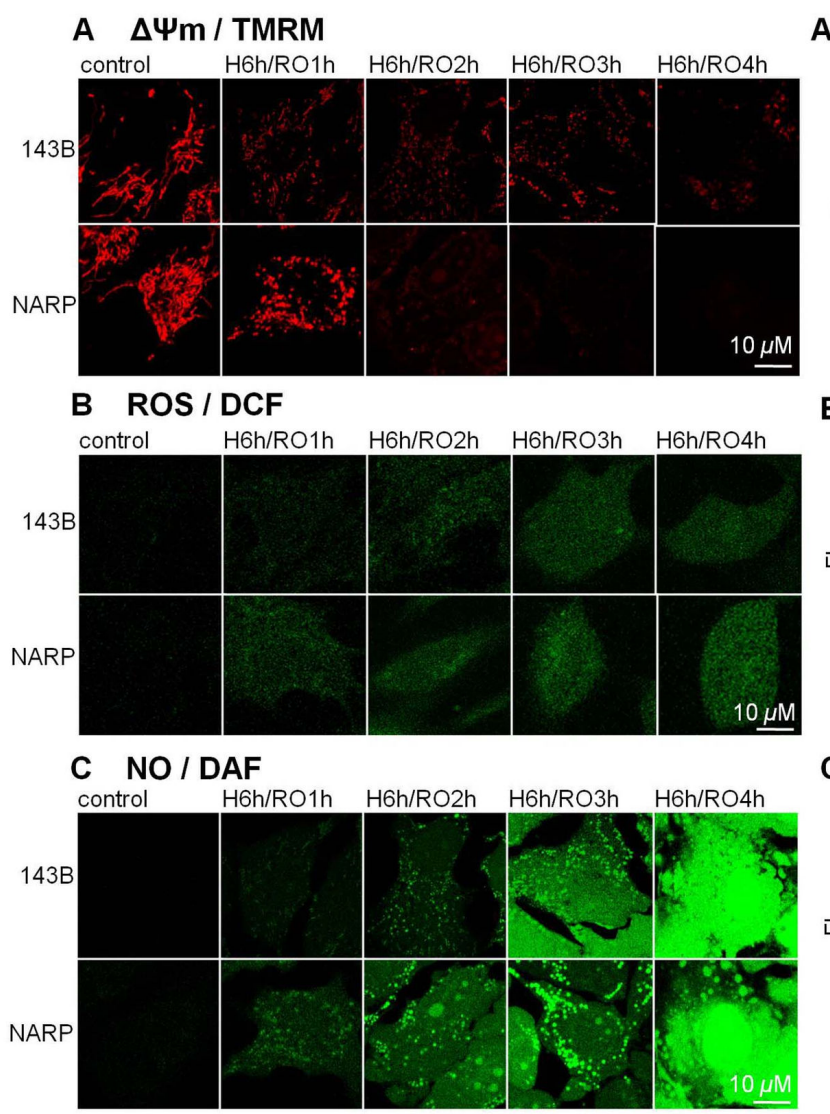

D Cardiolipin / NAO
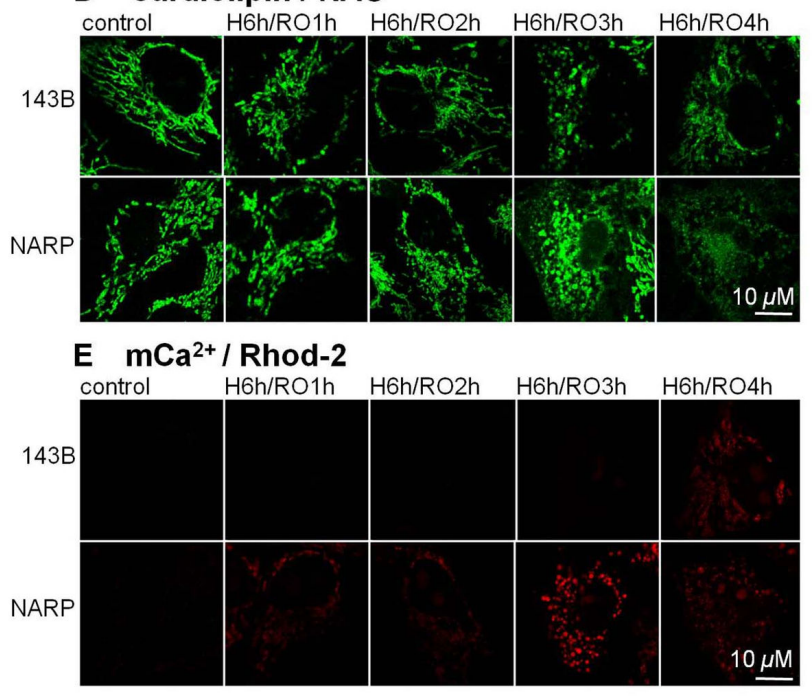

$A^{\prime}$
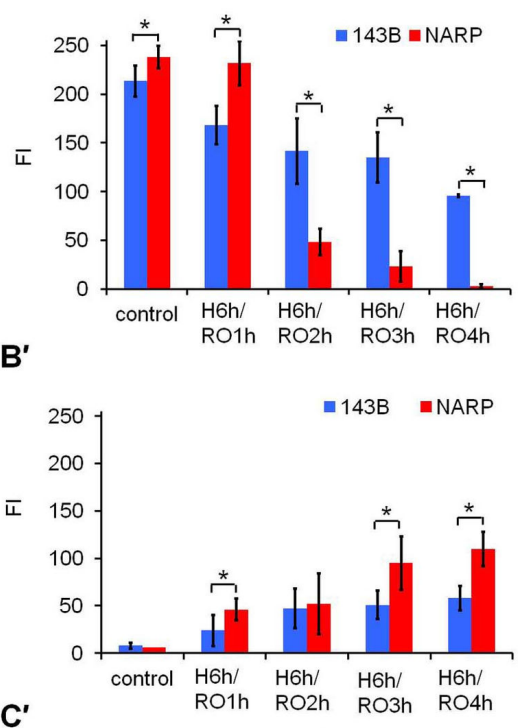

$\mathbf{C}^{\prime}$
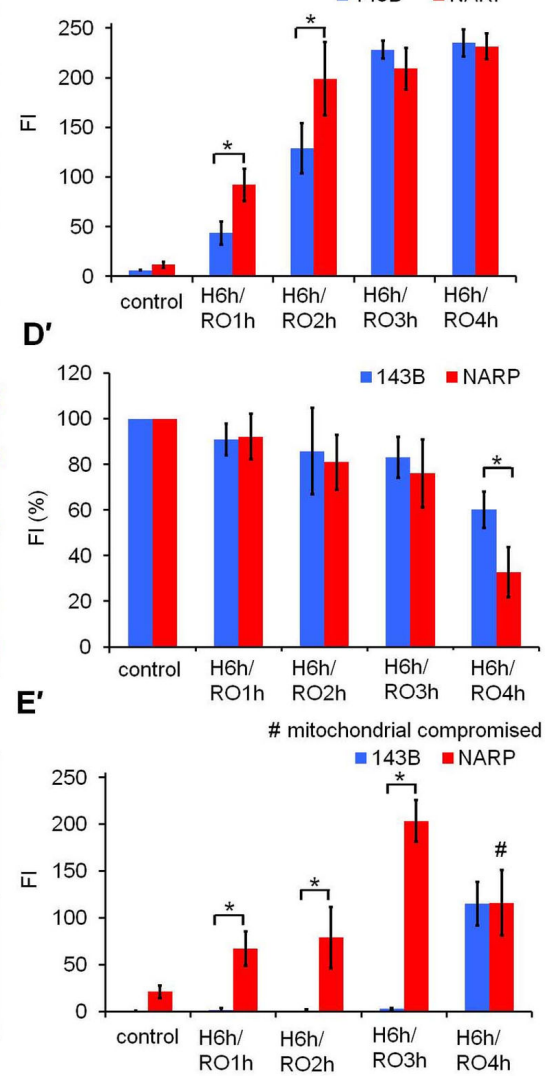

Figure 2. NARP augmented mitochondrial dysfunction upon H/RO. (A) NARP and longer reoxygenation durations augmented $\mathrm{H} / \mathrm{RO}(\mathrm{H}: 6 \mathrm{~h}$; RO: 1-4 h)-induced mitochondrial membrane potential $(\Delta \Psi \mathrm{m})$ depolarization. (B) After $\mathrm{H} / \mathrm{RO}$ with longer reoxygenation duration, mitochondrial reactive oxygen species (mROS) formation increased in both 143B cells and NARP cybrids. NARP augmented mROS formation. (C) After H/RO with longer reoxygenation duration, mitochondrial nitric oxide (mNO) formation increased in both 143B cells and NARP cybrids. NARP augmented the effect of H/RO on mNO formation. (D) Longer reoxygenation durations and NARP augmented cardiolipin depletion. (E) NARP augmented the effect of $H / R O$ on $\mathrm{mCa}^{2+}$ accumulation. (A'-E') Quantitative analyses of A-E. Mitochondrial compromised is indicated (\#). P-value representing statistically significant differences between NARP cybrids and $143 \mathrm{~B}$ cells $(P<0.05)$ is indicated $\left(^{*}\right) . \mathrm{n}=6$.

doi: 10.1371/journal.pone.0081546.g002 

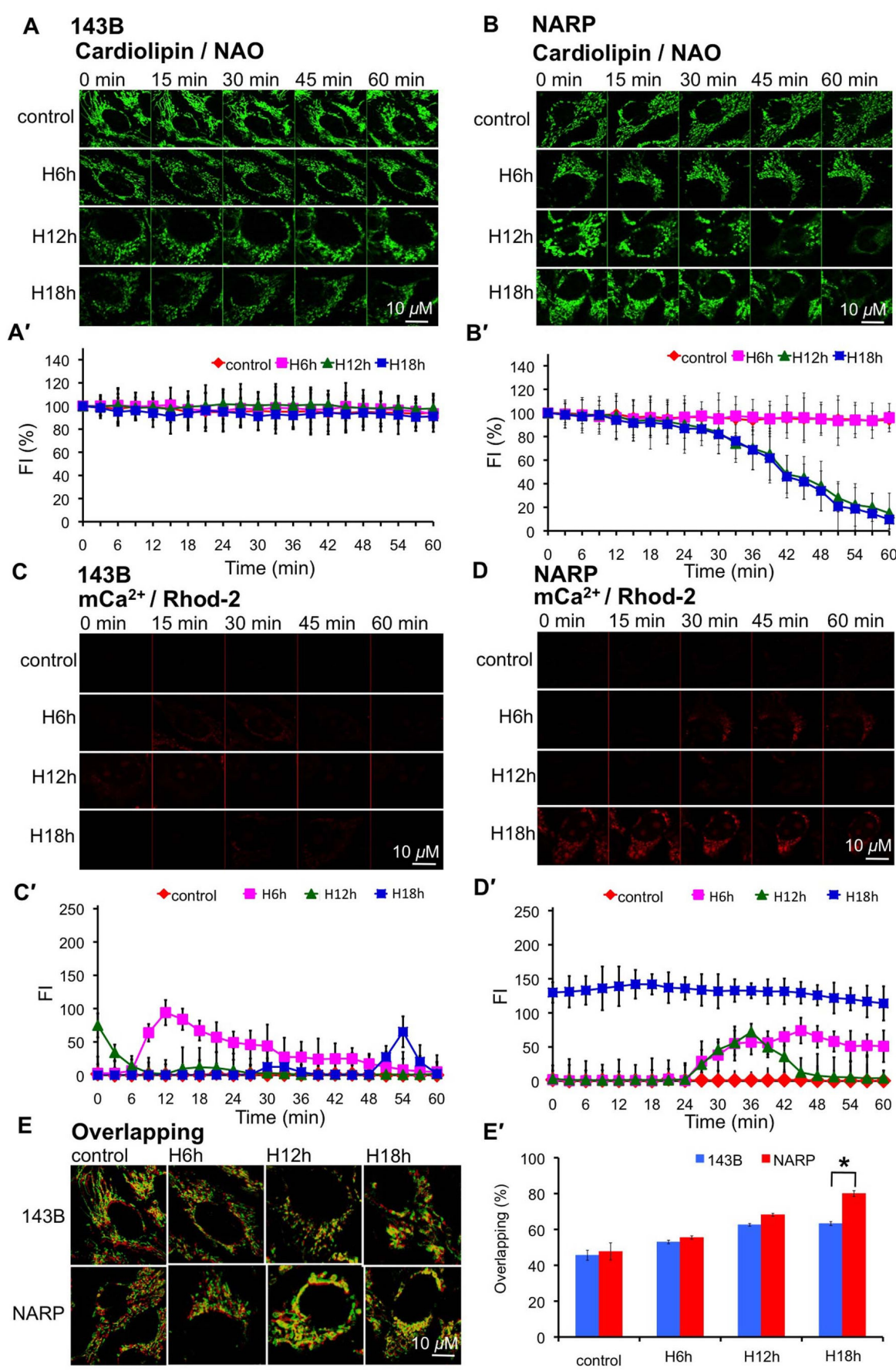

B' $^{\prime}$
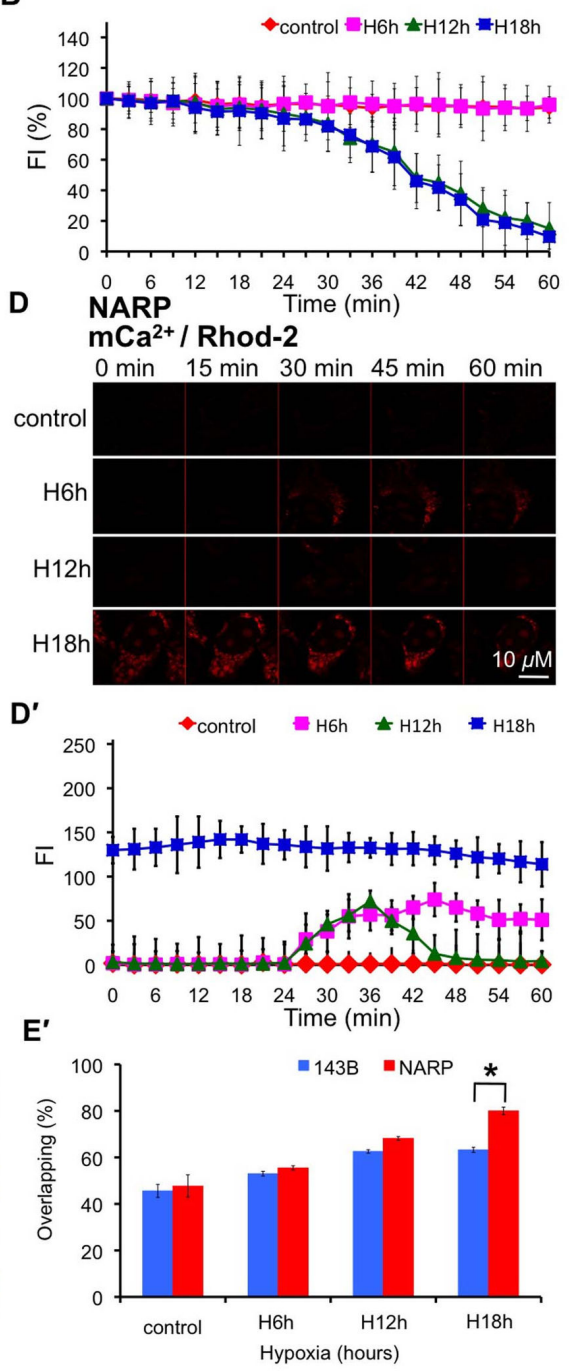

Figure 3. Effects of H/RO (with different hypoxia durations) on mitochondrial functions in NARP cybrids and 143B cells. (A) After treating 143B cells with $\mathrm{H} / \mathrm{RO}(\mathrm{H}: 6,12$, and $18 \mathrm{~h}$; RO: $2 \mathrm{~h})$, no obvious cardiolipin depletion was noted during recording. Mitochondria remained thread-like. (B) Cardiolipin depletion was noted gradually in NARP cybrids receiving H/RO with durations of hypoxia for 12 and $18 \mathrm{~h}$. Mitochondria became swollen and round. (C) In $143 \mathrm{~B}$ cells, only transient mCa ${ }^{2+}$ accumulation was noted (D) Marked and persistent $\mathrm{mCa}^{2+}$ accumulation was noted in NARP cybrids exposed to H/RO with duration of hypoxia for $18 \mathrm{~h}$. (E) Red/green overlay of two consecutive confocal images $(\Delta t=2 \mathrm{~min})$ of $80 \mathrm{nM}$ nonyl acridine orange (NAO) fluorescence in NARP cybrids and 143B cells upon $\mathrm{H} / \mathrm{RO}$ with different hypoxia durations. The percentage of nonmoving mitochondria (overlapping mitochondrial area, in yellow color) to total mitochondrial area increased from $45 \pm 3.2 \%$ to $63 \pm 1.4 \%$ in $143 \mathrm{~B}$ cells and $48 \pm 5.1 \%$ to $77 \pm 2.3 \%$ in NARP cybrids after the exposure of cells to $\mathrm{H} / \mathrm{RO}$ with duration of hypoxia for $18 \mathrm{~h}$. P-value representing statistically significant differences between NARP cybrids and 143B cells is indicated ( $\left.{ }^{*}\right)$. ( $\left.A^{\prime}-E^{\prime}\right)$ Quantitative analyses of $A-E$. $n=6$.

doi: 10.1371/journal.pone.0081546.g003 
and $48 \pm 5.1 \%$ in NARP cells. After $\mathrm{H} / \mathrm{RO}$ treatment (with different durations of hypoxia and the same duration of reoxygenation), the non-moving mitochondrial population analyzed from the percentage of the overlapping area (yellow area) of two consecutive images to total mitochondrial area increased to $63 \pm 1.4 \%$ in $143 \mathrm{~B}$ cells and to $77 \pm 2.3 \%$ in NARP cybrids after the exposure of cells to hypoxia for $18 \mathrm{~h}$ (Figure 3E, E'). Interestingly, the percentage of the ratio of nonmoving mitochondria to the entire mitochondrial population after and before $\mathrm{H} / \mathrm{RO}$ treatment $(\mathrm{H}$ : $18 \mathrm{~h}$; RO: $2 \mathrm{~h}$ ) was higher in NARP cybrids (NARP: $160 \%$ and 143B: $140 \%, P<0.05)$. These results suggested that the NARP-induced inhibition of F1F0-ATPase significantly augmented the retardation of mitochondrial movement after $\mathrm{H} / \mathrm{RO}$ treatment with prolonged duration of hypoxia.

\section{Melatonin Reduces H/RO-induced Apoptosis in Both NARP cybrids and 143B Cells}

Next, we investigated that whether melatonin, a potent mitochondrial protector, has a protective effect in response to $\mathrm{H} / \mathrm{RO}$ insults in NARP cybrids and 143B cells, We used H/RO treatment with hypoxia for $6 \mathrm{~h}$ and reoxygenation for $2 \mathrm{~h}$ in the following experiments since it could have induced moderate effects on mitochondrial parameters in previous dosedependent experiments. The result of MTT assay demonstrated that addition of $100 \mu \mathrm{m}$ melatonin during $\mathrm{H} / \mathrm{RO}$ $(\mathrm{H}: 6 \mathrm{~h}, \mathrm{RO}: 2 \mathrm{~h})$ treatment improved the percentage of cell survival in both 143B and NARP cells from $82 \pm 3.2 \%$ and $58 \pm$ $2.1 \%$ to $95 \pm 5.1 \%$ and $89 \pm 4.3 \%$, respectively $(P<0.05)$ (Figure 4A columns 2 and 4). The trypan blue exclusion test of cell viability also showed that addition of $100 \mu \mathrm{m}$ melatonin during $\mathrm{H} / \mathrm{RO}(\mathrm{H}: 6 \mathrm{~h}, \mathrm{RO}: 2 \mathrm{~h})$ treatment reduced the percentage of cell death in both 143B and NARP cells from 27 $\pm 4.1 \%$ and $56 \pm 6.3 \%$ to $12 \pm 5.4 \%$ and $27 \pm 4.6 \%$, respectively $(P<0.05)$ (Figure $4 \mathrm{~B}$ columns 2 and 4 ). For generating a stress mimic of stronger reoxygenation insults, we added a secondary oxidative stress $\left(\mathrm{H}_{2} \mathrm{O}_{2} 5 \mathrm{mM}\right)$ following $\mathrm{H} / \mathrm{RO}$ treatment to augment the $\mathrm{H} / \mathrm{RO}$ insults. The result of MTT assay demonstrated that addition of melatonin during $\mathrm{H} / \mathrm{RO}$ treatment improved cell survival in 143B cells and NARP cybrids in response to $\mathrm{H}_{2} \mathrm{O}_{2}$-augmented $\mathrm{H} / \mathrm{RO}$ insults from $42 \pm$ $6.1 \%$ and $37 \pm 6.3 \%$ to $62 \pm 8.1 \%$ and $55 \pm 4.2 \%$, respectively $(P<0.05)$ (Figure 4B. columns 4 and 5$)$. The trypan blue exclusion test of cell viability also showed that addition of melatonin during $\mathrm{H} / \mathrm{RO}$ treatment reduced the percentage of cell death in 143B cells and NARP cybrids in response to $\mathrm{H}_{2} \mathrm{O}_{2}$ augmented $\mathrm{H} / \mathrm{RO}$ insults from from $61 \pm 8.5 \%$ and $79 \pm 6.9 \%$ to $37 \pm 9.6 \%$ and $51 \pm 7.5 \%$, respectively $(P<0.05)$ (Figure 4B. columns 4 and 5)

\section{Melatonin Reduces NARP-enhanced H/RO-induced mROS Formation}

To explore whether melatonin-reduced apoptotic death in response to $\mathrm{H} / \mathrm{RO}$ insult is through suppressing $\mathrm{mROS}$ formation and protecting $\Delta \Psi_{\mathrm{m}}$, and whether NARP-induced inhibition of F1F0-ATPase disrupt these effects, we measured mROS using $2 \mu \mathrm{m}$ DCFH-DA and $200 \mathrm{nM} \Delta \Psi \mathrm{m}$ using TMRM in NARP cybrids and 143B cells after $\mathrm{H} / \mathrm{RO}$ treatment $(\mathrm{H}$ : $6 \mathrm{~h}$,
RO: 2h) and administering $\mathrm{H}_{2} \mathrm{O}_{2} \quad 5 \mathrm{mM}$ following $\mathrm{H} / \mathrm{RO}$ treatment. It was obvious that $\mathrm{H}_{2} \mathrm{O}_{2}$-augmented $\mathrm{H} / \mathrm{RO}$ insults induced a significant mROS formation in both NARP cybrids and 143B cells. Moreover, NARP greatly enhanced the effect of mROS formation (fluorescent intensity of DCF, recorded at 30 min after adding $\mathrm{H}_{2} \mathrm{O}_{2} \mathrm{NARP} / 143 \mathrm{~B}=1.5, \quad P<0.05$ )(Figure S2C-D; Figure 5C, $\left.C^{\prime}, \mathrm{D}, \mathrm{D}^{\prime}\right)$. Adding $100 \mu \mathrm{m}$ melatonin during $\mathrm{H}_{2} \mathrm{O}_{2}$-augmented $\mathrm{H} / \mathrm{RO}$ treatment suppressed mROS formation and protected $\Delta \Psi_{\mathrm{m}}$ from depolarization in NARP cybrids and 143B cells $(P<0.05)$ (Figure S2, Figure 5$)$. The above results indicated that the protection of NARP cybrids and 143B cells from $\mathrm{H}_{2} \mathrm{O}_{2}$-augmented $\mathrm{H} / \mathrm{RO}$ treatment by melatonin was due to suppression of mROS formation and $\Delta \Psi_{\mathrm{m}}$ depolarization. Moreover, the NARP-induced inhibition of F1F0-ATPase augmented mROS formation significantly in response to $\mathrm{H}_{2} \mathrm{O}_{2}$ augmented $\mathrm{H} / \mathrm{RO}$ treatment, but melatonin still could suppress mROS formation in NARP cybrids.

\section{Melatonin Reduces mROS-mediated Cardiolipin Depletion and $\mathrm{mCa}^{2+}$ Accumulation upon $\mathrm{H} / \mathrm{RO}$ in Both NARP Cybrids and 143B Cells}

To investigate how melatonin inhibited NARP-enhanced mROS formation in response to $\mathrm{H}_{2} \mathrm{O}_{2}$-augmented $\mathrm{H} / \mathrm{RO}$ insults, and if the content of cardiolipin and the levels of $\mathrm{mCa}^{2+}$ were altered, we measured cardiolipin using $80 \mathrm{nM} \mathrm{NAO}$ and $\mathrm{mCa}^{2+}$ using $2 \mu \mathrm{m}$ Rhod-2 at the same time after $\mathrm{H} / \mathrm{RO}$ treatment. After $\mathrm{H}_{2} \mathrm{O}_{2}$-enhanced $\mathrm{H} / \mathrm{RO}$ insults, NARP-induced inhibition of F1F0-ATPase significantly augmented the mROSmediated depletion of cardiolipin in comparison with 143B cells (NAO fluorescent intensity (\%) in 143B/ NAO fluorescent intensity $(\%)$ in NARP $=7$, recording at $30 \mathrm{~min}$ after adding $\mathrm{H}_{2} \mathrm{O}_{2}, \mathrm{P}<0.05$ ) (Figure S3A-B; Figure 6A, A', B, B'). NARP also enhanced the accumulation of $\mathrm{mCa}^{2+}$ in response to $\mathrm{H}_{2} \mathrm{O}_{2}$ enhanced $\mathrm{H} / \mathrm{RO}$ insults $(P<0.05$, compared between $\mathrm{H} / \mathrm{RO}$ group of NARP and $143 \mathrm{~B}$ cells). No obvious $\mathrm{mCa}^{2+}$ accumulation was noted in $143 \mathrm{~B}$ cells upon $\mathrm{H} / \mathrm{RO}$ treatment (fluorescence intensity $<10$ during recording) (Figure S3C-D; Figure 6C, C', D, D'). Interestingly, melatonin $(100 \mu \mathrm{m})$ significantly protected $\mathrm{mROS}$-mediated depletion of cardiolipin in both NARP cybrids and 143B cells upon $\mathrm{H}_{2} \mathrm{O}_{2}$-augmented $\mathrm{H} / \mathrm{RO}$ treatment $(P<0.05)$ (Figure S3A-B; Figure $\left.6 \mathrm{~A}, \mathrm{~A}^{\prime}, \mathrm{B}, \mathrm{B}^{\prime}\right)$. In addition, melatonin also suppressed $\mathrm{mCa}^{2+}$ accumulation in response to $\mathrm{H}_{2} \mathrm{O}_{2}$-augmented $\mathrm{H} / \mathrm{RO}$ insults in NARP cybrids $(P<0.05)$ (Figure S3C-D; Figure 6C, C', D, D'). These results indicated that the NARP-induced inhibition of F1F0-ATPase greatly enhanced mROS formation and $\mathrm{mCa}^{2+}$ accumulation after $\mathrm{H}_{2} \mathrm{O}_{2}$-augmented $\mathrm{H} / \mathrm{RO}$ insults, which led to mROSmediated depolarization of $\Delta \Psi_{\mathrm{m}}$ and depletion of cardiolipin. Melatonin significantly prevented mROS-mediated depletion of cardiolipin upon $\mathrm{H}_{2} \mathrm{O}_{2}$-augmented $\mathrm{H} / \mathrm{RO}$ treatment in both NARP cybrids and 143B cells. To investigate if the melatoninrelated protection is primary through reducing overall $\mathrm{mROS}$, we administered a mitochondrial specific antioxidant mitoQ $(0.2$ $n M)$ or a general antioxidant vitamin $\mathrm{E}(200 \mu \mathrm{m})$ during $\mathrm{H}_{2} \mathrm{O}_{2}-$ augmented $\mathrm{H} / \mathrm{RO}$ insults for comparison and evaluated their protective effects on $\mathrm{mROS}, \Delta \Psi \mathrm{m}, \mathrm{mCa}^{2+}$, and cardiolipin (Figure S4-7). The effect of mitoQ on $\mathrm{mROS}$ suppression was 
A

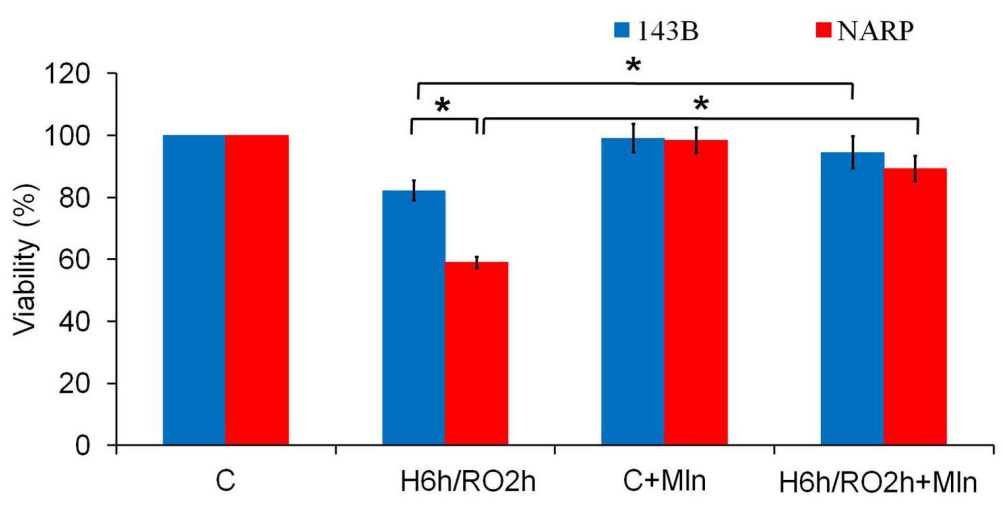

B
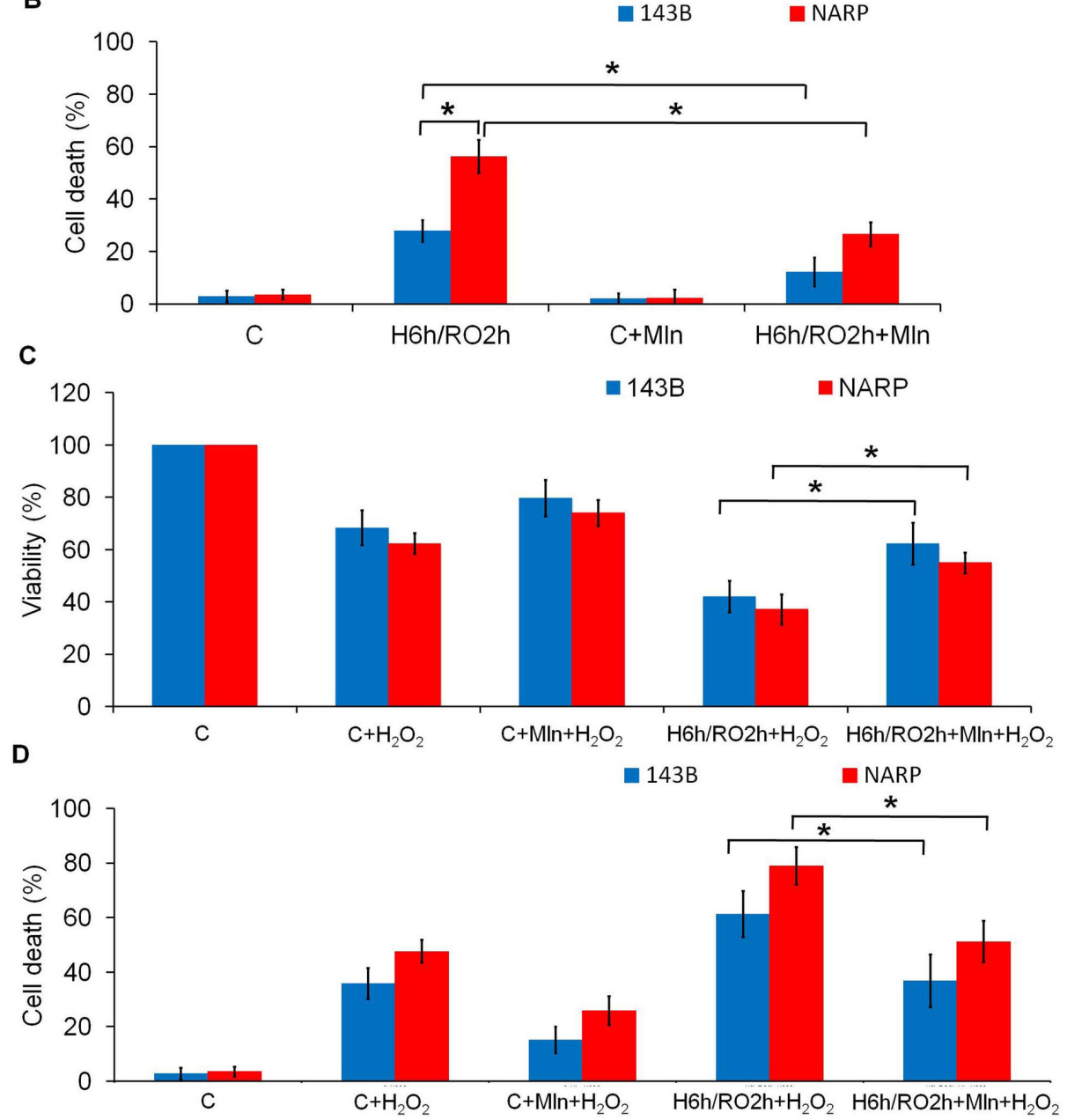

Figure 4. Effects of melatonin on cell viability in NARP cybrids and 143B cells in response to H/RO. (A) MTT assay. After $\mathrm{H} / \mathrm{RO}(\mathrm{H}: 6 \mathrm{~h}, \mathrm{RO}: 2 \mathrm{~h}$ ), apoptotic death was noted in NARP cybrids and 143B cells (death ratio: NARP > 143B) (column 2). Adding melatonin $100 \mu \mathrm{m}$ during $\mathrm{H} / \mathrm{RO}$ significantly reduced NARP-augmented cell death (column 4). (B) Trypan blue exclusion test of cell viability. Addition of $100 \mu \mathrm{m}$ melatonin during $\mathrm{H} / \mathrm{RO}$ treatment reduced the percentage of cell death in both 143B and NARP cells

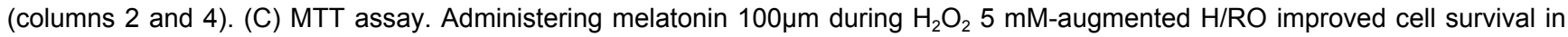
both NARP cybrids and 143B cells (column 4 and 5). (D) Trypan blue exclusion test of cell viability. Addition of melatonin during $\mathrm{H} / \mathrm{RO}$ treatment reduced the percentage of cell death in 143B and NARP cybrids in response to $\mathrm{H}_{2} \mathrm{O}_{2}$-augmented $\mathrm{H} / \mathrm{RO}$ insults (columns 4 and 5). Each value represents the mean \pm S.E. of three independent determinations. P-values representing statistically significant differences between NARP and 143B cells upon $\mathrm{H} / \mathrm{RO}$; without melatonin and with melatonin during $\mathrm{H} / \mathrm{RO}$ (both in the groups with and without secondary $\mathrm{H}_{2} \mathrm{O}_{2}$ stress) are indicated $\left(^{*}\right)$. Mln: melatonin.

doi: 10.1371/journal.pone.0081546.g004 


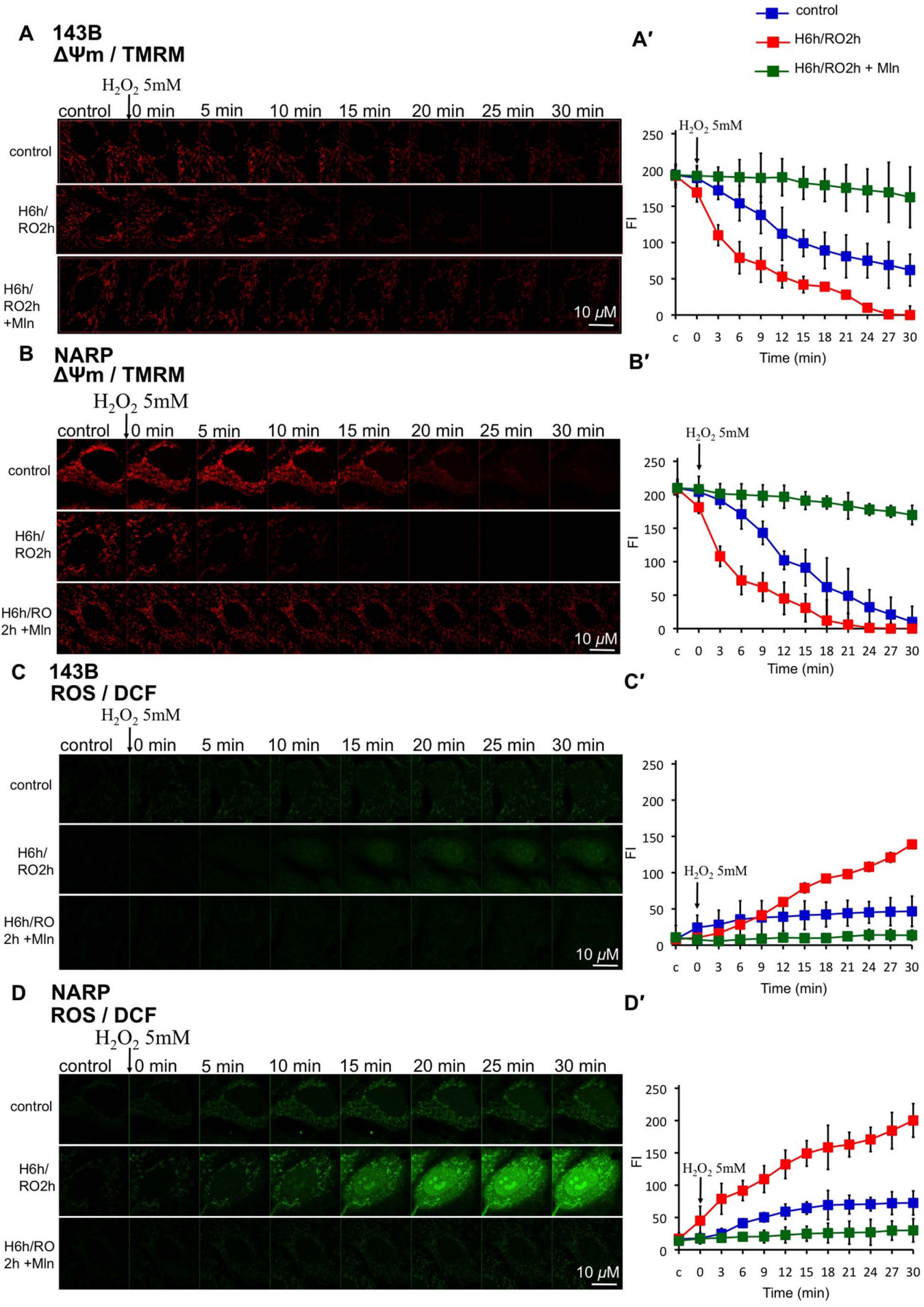

Figure 5. Effects of melatonin on $\Delta \Psi \mathrm{m}$ and $\mathrm{mROS}$ upon $\mathrm{H}_{2} \mathrm{O}_{2}$-augmented $\mathrm{H} / \mathrm{RO}$ in $143 \mathrm{~B}$ cells and NARP cybrids. (A, B) In both $143 \mathrm{~B}$ cells and NARP cybrids, $\Delta \Psi \mathrm{m}$ depolarization was faster in the group with $\mathrm{H}_{2} \mathrm{O}_{2}(5 \mathrm{mM})$-augmented $\mathrm{H} / \mathrm{RO}(\mathrm{H}: 6 \mathrm{~h}$; $\mathrm{RO}: 2$ h); NARP augmented this effect. Adding melatonin $100 \mu \mathrm{m}$ during $\mathrm{H}_{2} \mathrm{O}_{2}$-augmented $\mathrm{H} / \mathrm{RO}$ effectively protected $\Delta \Psi \mathrm{m}$ from depolarization. (C) In 143B cells, more mROS formation was noted in the group of $\mathrm{H}_{2} \mathrm{O}_{2}$-augmented $\mathrm{H} / \mathrm{RO}$. Adding melatonin during $\mathrm{H}_{2} \mathrm{O}_{2}$-augmented $\mathrm{H} / \mathrm{RO}$ effectively suppressed mROS formation. (D) In NARP cybrids, mROS formation was augmented as compared with 143B cells. Adding melatonin during $\mathrm{H}_{2} \mathrm{O}_{2}$-augmented $\mathrm{H} / \mathrm{RO}$ still effectively suppressed mROS formation. ( $\mathrm{A}^{\prime}-\mathrm{D}^{\prime}$ ) Quantitative analyses of A-D. $n=6$. FI: fluorescence intensity. Mln : melatonin.

doi: 10.1371/journal.pone.0081546.g005 
better than vitamin $E$ in response to $\mathrm{H}_{2} \mathrm{O}_{2}$-augmented $\mathrm{H} / \mathrm{RO}$ insults (Figure S4, S6).

\section{Melatonin Improves H/RO-induced Retardation of Mitochondrial Movement in Both NARP Cybrids and 143B Cells}

Finally, we investigated whether the melatonin-induced protection of cardiolipin in NARP cybrids and 143B cells improved the retardation of mitochondrial movement in response to $\mathrm{H} / \mathrm{RO}$ insults. After $\mathrm{H} / \mathrm{RO}$ treatment $(\mathrm{H}$ : $6 \mathrm{~h}, \mathrm{RO}$ : $2 \mathrm{~h}$ ), we loaded the cells with $200 \mathrm{nM}$ TMRM, and mitochondrial movement was analyzed using time-lapse imaging continuously both with and without melatonin in 143B cells and NARP cybrids. H/RO treatment significantly induced the retardation of mitochondrial movement in 143B cells and NARP cybrids, so that the non-moving mitochondrial population analyzed from the percentage of the overlapping area (yellow area) of two consecutive images (the first image labeled red in color and the second image labeled green in color, taken $2 \mathrm{~min}$ apart) to total mitochondrial area (mitochondrial area in the first image) increased from $45 \pm 2.3 \%$ to $57 \pm 1.4 \%$ in $143 \mathrm{~B}$ cells $(P<0.05)$, and from $65 \pm 1.9 \%$ to $76 \pm 1.4 \%$ in NARP cybrids $(P<0.05)$. Administering $100 \mu \mathrm{m}$ melatonin during $\mathrm{H} / \mathrm{RO}$ treatment significantly improved the retardation of mitochondrial movement, so that the non-moving mitochondrial population analyzed from the percentage of the overlapping area (yellow area) of two consecutive images to total mitochondrial area decreased from $57 \pm 1.4 \%$ to $48 \pm 1.2 \%$ in $143 \mathrm{~B}$ cells $(P<0.05)$, and from $76 \pm 1.4 \%$ to $63 \pm 2.2 \%$ in NARP cybrids $(P<0.05)$ (Figure 7$)$.

\section{Discussion}

In the present study, by using the cells with NARP-induced inhibition of F1F0-ATPase, we demonstrated for the first time that NARP-induced inhibition of F1F0-ATPase-augmented $\mathrm{H} / \mathrm{RO}$ insult-induced apoptosis. NARP-augmented H/RO insult was closely associated with a pathological enhancement of mROS formation, which led to accumulation of $\mathrm{mCa}^{2+}$, depolarization of $\Delta \Psi \mathrm{m}$, and more severe depletion of the protective mitochondrial phospholipid cardiolipin. The above results led to the more severe retardation of mitochondrial movement, and then activated the opening of mPTP in NARP cybrids. Interestingly, melatonin significantly improved cells survival by preventing mROS-mediated cardiolipin depletion and $\mathrm{mCa}^{2+}$ accumulation, and rescued the retardation of mitochondrial movement in NARP cybrids in response to $\mathrm{H} / \mathrm{RO}$ insults. To our knowledge, this is the first report to elucidate the influence of NARP-induced inhibition of F1F0-ATPase on H/RO insults-induced mitochondrial dysfunction and the protective action of melatonin in NARP cybrids in response to the $\mathrm{H} / \mathrm{RO}$ insults. The precise schematic illustration of NARP-induced inhibition of F1F0-ATPase augmentation of mitochondrial dysfunction upon $\mathrm{H} / \mathrm{RO}$ treatment and the protections by melatonin in NARP cybrids is shown in Figure 8.

The reason that NARP-induced F1F0-ATPase inhibition augments mROS formation in response to $\mathrm{H} / \mathrm{RO}$ treatment is still unknown. Previous studies suggested that the hyperpolarized $\Delta \Psi_{\mathrm{m}}$ in NARP cells leads to the decreased activity of the mitochondrial respiratory chain as a consequence of F1F0-ATPase inhibition and mitochondrial coupling thus resulting in enhanced mROS formation [34,35]. Our recent study had also demonstrated that NARP enhanced mROS formation upon other apoptotic insults (e.g., amyloidBtreatment and focal laser irradiation-induced ROS stress) [36]. In addition, our group also previously observed that defect of mIDNA augmented mROS formation with enhancement of apoptosis in common deletion (mtDNA 4977 bp deleted) cybrids $[37,38]$ and in RBA-1 astrocytes containing defective mitochondrial complex I because of long-term rotenone exposure (RT-RBA-1 cells, unpublished data) suggesting that mtDNA mutations or complex defects may potentially enhance several neurodegenerative disorders and even the H/RO injury.

Our group previously demonstrated that cardiolipin is a crucial pathological target for mitochondrial apoptotic insults (e.g., $\mathrm{H}_{2} \mathrm{O}_{2}$, arachidonic acid, ionomycin) in NARP cybrids, [21]. In the current study, we demonstrated that cardiolipin is an important pathological target for $\mathrm{H} / \mathrm{RO}$ insults in cells with NARP-induced inhibition of F1F0-ATPase. Previous studies had demonstrated that NARP enhances the production of toxic mROS [35,39]. In this study, we confirmed that NARPaugmented mROS formation led to more severe depletion or peroxidation of cardiolipin. It is well known that mROS-induced cardiolipin peroxidation leads to impaired mitochondrial function and depressed respiratory chain [40-42]. mROS production, cardiolipin depletion/peroxidation, and respiratory chain impairment are linked to each other to create a vicious cycle that leads to the decline of mitochondrial bioenergetics and subsequent mitochondrial dysfunction associated with $\mathrm{H} / \mathrm{RO}$ insults [43]. In addition, peroxidized cardiolipin can behave as an inducer of mPTP opening, which lowers the threshold of $\mathrm{Ca}^{2+}$ for inducing this process and/or potentiating the effect of $\mathrm{Ca}^{2+}$ in mPTP opening. The effect of peroxidized cardiolipin on $\mathrm{mPTP}$ is associated with a release of cytochrome $c$ from the mitochondria $[44,45]$. It is thus conceivable that NARP-augmented mROS formation upon $\mathrm{H} / \mathrm{RO}$ treatment induces more severe depletion and peroxidation of cardiolipin, which contribute to MPTP opening, cytochrome c release, and more severe cell death.

NARP-induced inhibition of F1F0-ATPase possibly augments the retardation of mitochondrial movement in response to $\mathrm{H} / \mathrm{RO}$ insults through the depletion of cardiolipin. Our previous study suggested that cardiolipin is a crucial modulator for the interaction between mitochondria and motor proteins of the microtubule for maintaining normal mitochondrial movement [21]. Upon mitochondrial apoptotic insults (we used $\mathrm{H}_{2} \mathrm{O}_{2}$, arachidonic acid or ionomycin treatment), mitochondria lose cardiolipin, which may result in retardation of mitochondrial movements. We propose that NARP-augmented depletion of cardiolipin upon $\mathrm{H} / \mathrm{RO}$ insults leads to weakening the mitochondria-microtubule interaction by loss of cardiolipin in mitochondria, and results in retardation of mitochondrial movement.

The beneficial effects of melatonin ( $\mathrm{N}$-acetyl-5-methoxytryptamine) on human health are well known and are frequently associated with its antioxidant, or free radical-scavenging 


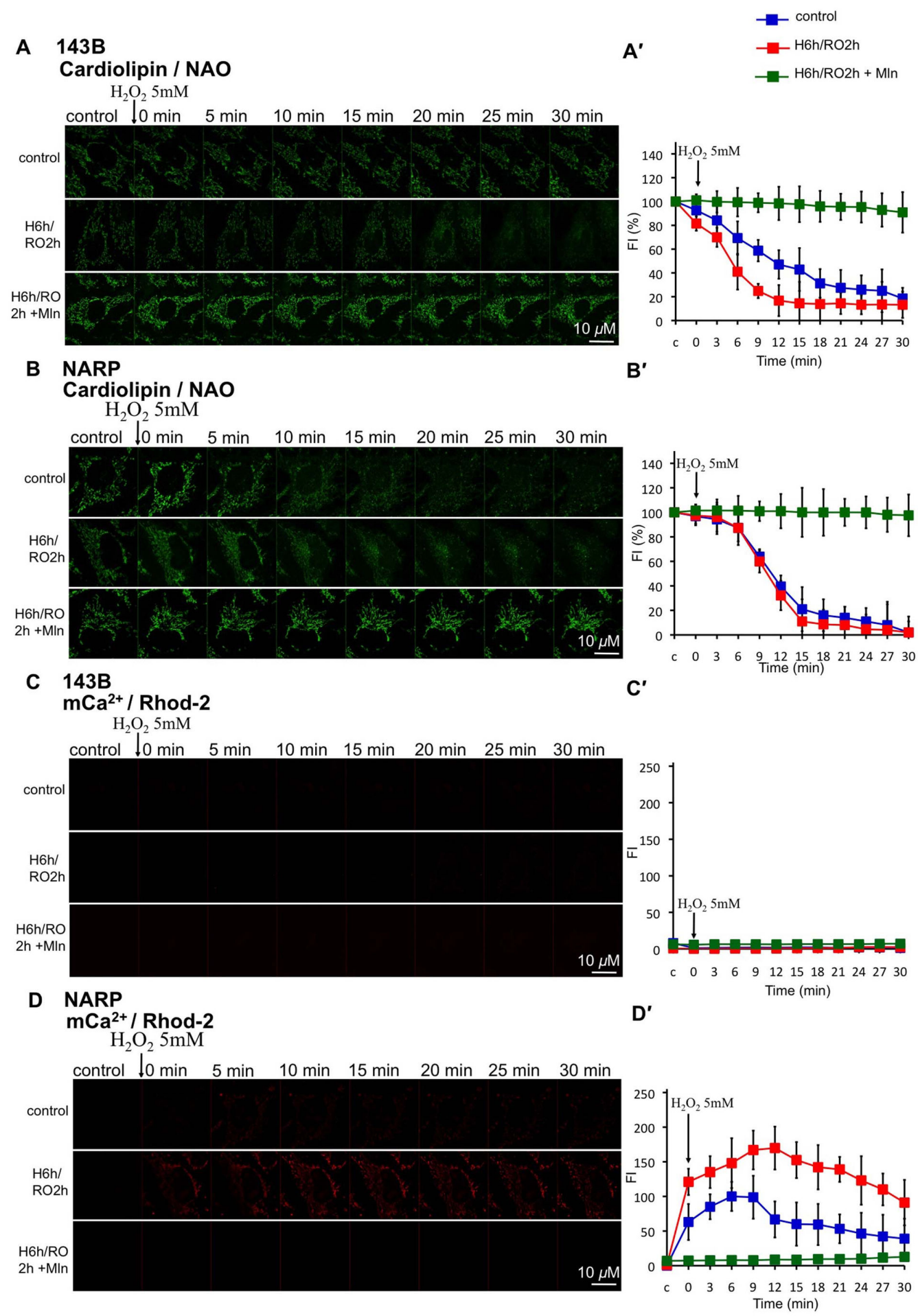

Figure 6. Effects of Melatonin on cardiolipin and $\mathrm{mCa}^{2+}$ upon $\mathrm{H}_{2} \mathrm{O}_{2}$-augmented $\mathrm{H} / \mathrm{RO}$ in 143B cells and NARP cybrids. (A) In 143B cells, cardiolipin depletion was augmented in the group with $\mathrm{H}_{2} \mathrm{O}_{2}$-augmented $\mathrm{H} / \mathrm{RO}(\mathrm{H}: 6 \mathrm{~h}$; RO: 2 h). Note that adding melatonin $100 \mu \mathrm{m}$ during $\mathrm{H}_{2} \mathrm{O}_{2}$-augmented $\mathrm{H} / \mathrm{RO}$ protected cardiolipin from depletion. (B) In NARP cybrids, cardiolipin depletion was augmented as compared with 143B cells, and adding melatonin during $\mathrm{H}_{2} \mathrm{O}_{2}$-augmented $\mathrm{H} / \mathrm{RO}$ protected cardiolipin from depletion. (C) In 143B cells, no obvious $\mathrm{mCa}^{2+}$ accumulation was noted in response to $\mathrm{H}_{2} \mathrm{O}_{2}$-augmented $\mathrm{H} / \mathrm{RO}$. (D) In NARP cybrids, mCa ${ }^{2+}$ accumulation was augmented in the group with $\mathrm{H}_{2} \mathrm{O}_{2}$-augmented $\mathrm{H} / \mathrm{RO}$. Adding melatonin during $\mathrm{H}_{2} \mathrm{O}_{2}$-augmented $\mathrm{H} / \mathrm{RO}$ suppressed $m \mathrm{ma}^{2+}$ accumulation. $\left(\mathrm{A}^{\prime}-\mathrm{D}^{\prime}\right)$ Quantitative analyses of $A-D . n=6$. Mln: melatonin.

doi: 10.1371/journal.pone.0081546.g006 


\section{A Overlapping}

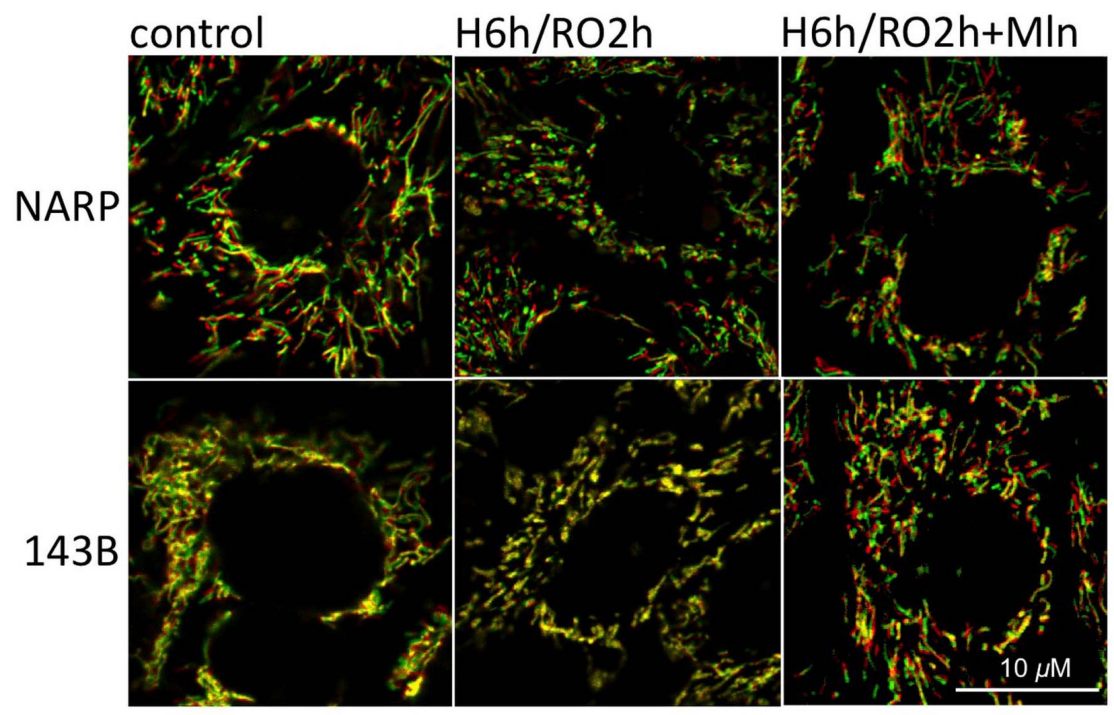

B Overlapping Percentage (\%)

\begin{tabular}{|l|l|l|l|}
\hline & Control & H6h/RO2h & H6h/RO2h + MIn \\
\hline 143B & $45 \pm 2.3$ & $57 \pm 1.4$ & $48 \pm 1.2$ \\
\hline NARP & $65 \pm 1.9$ & $76 \pm 1.4$ & $63 \pm 2.2$ \\
\hline
\end{tabular}

C

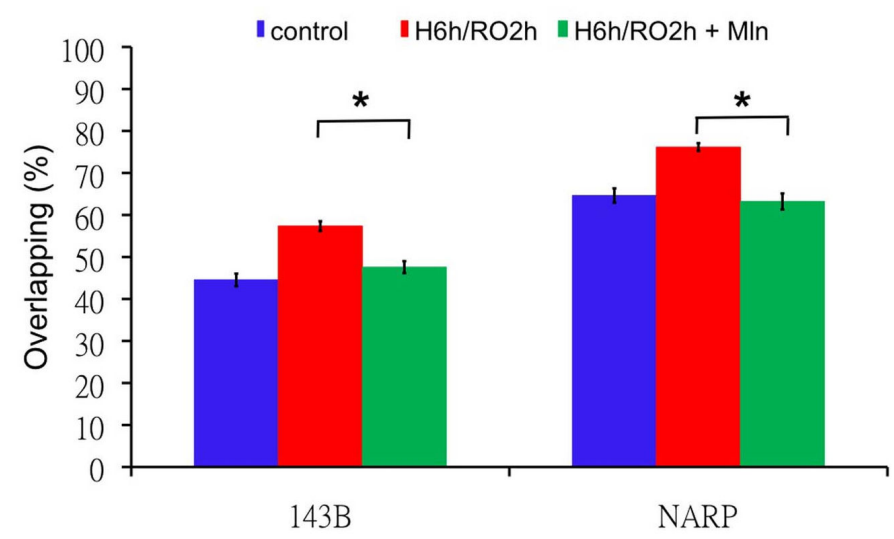

Figure 7. Melatonin significantly improved H/RO-induced retardation of mitochondrial movement in 143B cells and NARP cybrids. (A, B) Red/green overlay of two consecutive confocal images ( $\Delta \mathrm{t}=2 \mathrm{~min})$ of $200 \mathrm{nM}$ tetramethylrhodamine methyl ester (TMRM) fluorescence in NARP cybrids and 143B cells in response to $\mathrm{H} / \mathrm{RO}$ treatment without and with $100 \mu \mathrm{m} \mathrm{melatonin.} \mathrm{H} / \mathrm{RO}(\mathrm{H}$ : $6 \mathrm{~h}$; RO: $2 \mathrm{~h}$ ) reduced the velocity of mitochondrial movement in both 143B cells and NARP cybrids, so that the percentage of nonmoving mitochondria (overlapping mitochondrial area, in yellow color) to the entire mitochondria were $57 \pm 1.4 \%$ in $143 \mathrm{~B}$ cells and $76 \pm 1.4 \%$ in NARP cybrids as compared to the cells and cybrids, respectively, without $\mathrm{H} / \mathrm{RO}$ treatment. Adding melatonin 100 $\mu \mathrm{m}$ during $\mathrm{H} / \mathrm{RO}$ improved mitochondrial movement in both $143 \mathrm{~B}$ cells and NARP cybrids as compared with the groups without melatonin during $\mathrm{H} / \mathrm{RO}$, so that the percentage of nonmoving mitochondria to the all mitochondria was $48 \pm 1.2 \%$ in $143 \mathrm{~B}$ cells and $63 \pm 2.2 \%$ in NARP cybrids. (C) Quantitative analyses of $(A) .{ }^{*} P<0.05 . n=6$. Mln: melatonin.

doi: 10.1371/journal.pone.0081546.g007 


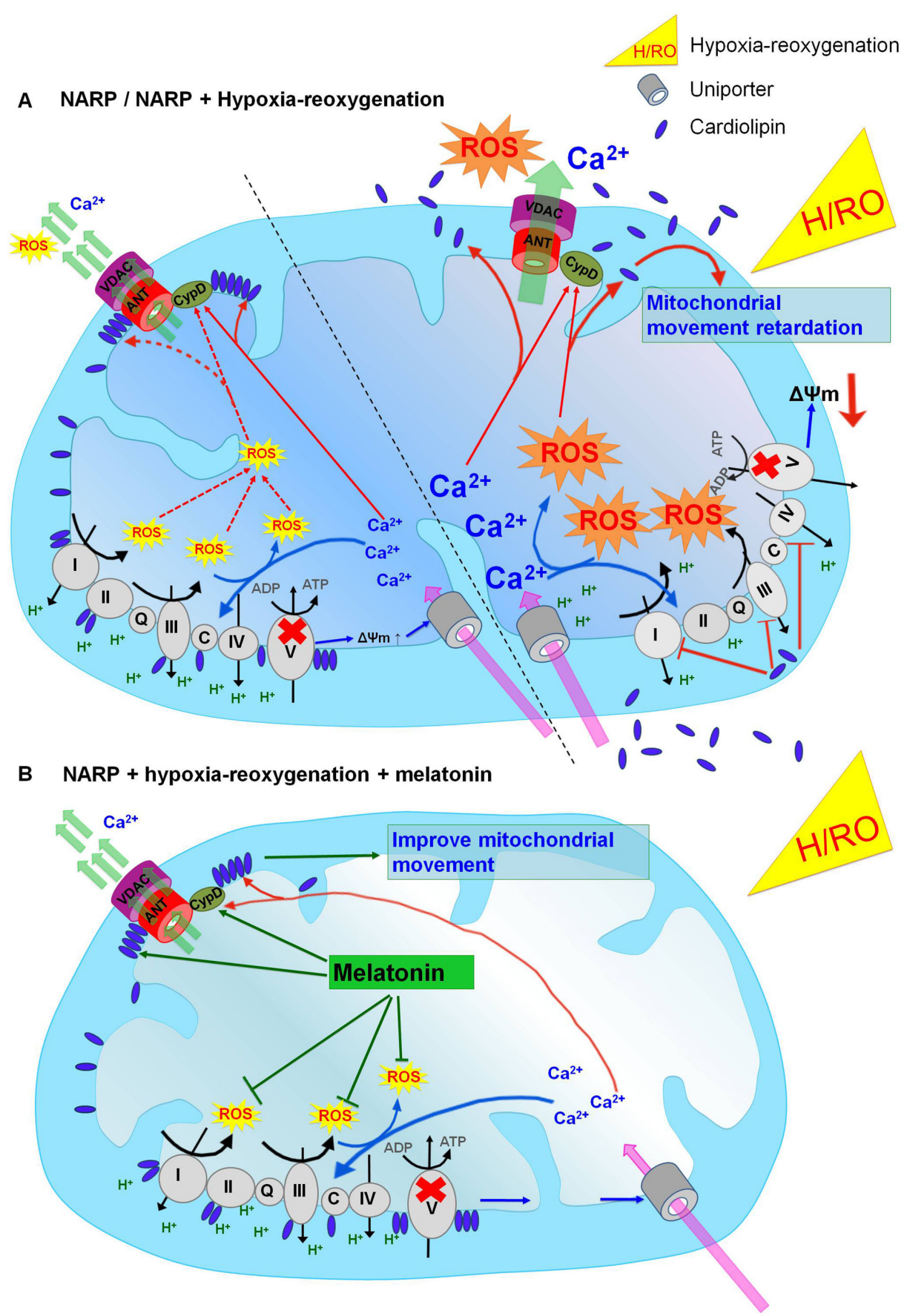

Figure 8. Schematic illustration of NARP-induced F1F0-ATPase defect. augments mitochondrial dysfunction upon H/RO. (A) Control NARP cybrids. The NARP mutation-induced inhibition of F1F0-ATP synthase results in hyperpolarization of the $\triangle \Psi \mathrm{m}$, which leads to enhanced basal mROS formation and $\mathrm{mCa}^{2+}$ accumulation. Both $\mathrm{mROS}$ and $\mathrm{mCa}^{2+}$ act synergistically to deplete cardiolipin, which leads to inadequate protective function of transient mitochondrial permeability transition (MPT) as compared with wild-type cells (left hand side). With H/RO, F1F0-ATP synthase fails to work in the reverse mode in NARP cybrids due to reduced ATP hydrolysis and unhealthy enzyme function, which results in depolarization of $\Delta \Psi \mathrm{m}$. In addition, NARP mutation augments $\mathrm{H} / \mathrm{RO}$-induced mROS formation and $\mathrm{mCa}^{2+}$ accumulation, which leads to more severe depletion of cardiolipin. The depletion of cardiolipin results in mitochondrial movement retardation, inhibition of complexes I, III and IV of the respiratory chain, and fatal opening of MPT pore (right hand side). (B) In the presence of melatonin during $\mathrm{H} / \mathrm{RO}, \mathrm{H} / \mathrm{RO}$-induced mROS formation is greatly reduced, which stabilize cardiolipin. Cardiolipin stabilization results in preservation of $\Delta \Psi \mathrm{m}$, improvement of mitochondrial movement, and suppressing fatal MPT.

doi: 10.1371/journal.pone.0081546.g008 
activity. The physiological distribution of melatonin is highest in the cell membrane, followed by mitochondria, nucleus, and cytosol [46]. The most unique property of melatonin is that its metabolites also have the ability to scavenge ROS and reactive nitrogen species. The continuous protection exerted by melatonin and its metabolites, referred to as the free radical scavenging cascade, makes melatonin highly effective, even at low concentrations, for protecting organisms from oxidative stress [47-49]. $\quad N^{1}$-acetyl- $N^{2}$-formyl-5-methoxykynuramine (AFMK) and $N[1]$-acetyl-5-methoxykynuramine (AMK), the metabolites of melatonin, have been found to exhibit protective effects against oxidative stress. In general, their protective activities against oxidative stress follow the order AMK > melatonin $>$ AFMK. The efficiency of melatonin for scavenging free radicals is predicted to be reduced when it is metabolized to AFMK and the efficiency of melatonin for scavenging the radicals in aqueous solution is predicted to be increased when it is metabolized to AMK [50,51]. The direct free radical scavenging activity of melatonin has been extensively studied. Interestingly, melatonin also has indirect antioxidative effects via the stimulation of antioxidative enzymes [52]. However, our results did not differentiate between the direct and indirect antioxidative effects of melatonin in response to $H / R O$ treatment. Furthermore, in addition to being a broad-spectrum antioxidant, melatonin is a ligand of several G-protein-coupled receptors. Two mammalian isoforms of the melatonin receptor (melatonin receptor 1 and 2) were identified in a previous study [53]. Previous studies have suggested that the melatonin receptor-ligand axis may play a pathogenic role in several neurodegenerative diseases and is critical for neuroprotection. Therefore, the indirect antioxidative effects of melatonin are presumed to be receptor-mediated [54].

Intriguingly, our result demonstrated that melatonin could preserve cardiolipin, prevent $\Delta \Psi_{\mathrm{m}}$ depolarization, suppress ROS formation, prevent $\mathrm{mCa}^{2+}$ accumulation, and rescue retardation of mitochondrial movement upon $\mathrm{H} / \mathrm{RO}$ insults in both NARP cybrids and 143B cells. Moreover, NARP-induced inhibition of F1F0-ATPase did not disrupt the protection generated by melatonin in response to $\mathrm{H} / \mathrm{RO}$ insults. Several recently published studies showed that melatonin and several of its metabolites (e.g., AFMK, AMK) have significant protective actions against cardiac damage induced during $\mathrm{H} / \mathrm{RO}$ treatment [23-27,55]. The possible mechanisms of the protective effect of melatonin during $\mathrm{H} / \mathrm{RO}$ treatment include: (1) melatonin is a potent and broad-spectrum antioxidant that antagonizes mitochondrial oxidative stress (2), melatonin can preserve the content and integrity of cardiolipin molecules, which inhibit mPTP opening through cardiolipin protection [56,57], (3) melatonin inhibits the opening of mPTP directly and this contributes to its neuroprotective effect in cerebral ischemia [56], (4) melatonin may have a direct targeting effect on $\mathrm{mCa}^{2+}$-mediated apoptotic events. Peng et al. recently suggested that melatonin directly stabilizes cardiolipin to prevent its depletion and peroxidation, which leads to improvement of mitochondrial movement [21]. Our finding in this study demonstrating that melatonin can rescue retardation of mitochondrial movement in NARP cybrids and 143B cells upon H/RO stress was in agreement with Peng et al's study.
The reason that NARP-induced inhibition of F1F0-ATPase does not disrupt the mitochondrial protective effects of melatonin upon $\mathrm{H} / \mathrm{RO}$ treatment is still being studied. Mattiazzi et al. had previously showed that antioxidants restore respiration and partially rescue ATP synthesis in NARP cybrids, suggesting that free radical-mediated inhibition of OXPHOS contributes to the loss of ATP synthesis [39]. Theoretically, the function of the electron transport chain (complex I to IV) is intact in NARP cybrids (which only have complex $\mathrm{V}$ defect), therefore, melatonin may also act on the electron transport chain but not on F1F0-ATPase to generate its mitochondrial protective effect upon H/RO treatment. Comparing the differences between NARP cybrids and 143B cells during $\mathrm{H} / \mathrm{RO}$ treatment in our data, it was obvious that NARP-induced inhibition of F1F0-ATPase augmented $\mathrm{mCa}^{2+}$ accumulation during $\mathrm{H} / \mathrm{RO}$ treatment, either by enhancement with longer reoxygenation duration, longer hypoxia duration or secondary oxidative stress. Further experiments such as using $\mathrm{Ca}^{2+}$-free HEPES solution or treating NARP cells with Ruthenium red to inhibit $\mathrm{mCa}^{2+}$ uniporter upon $\mathrm{H} / \mathrm{RO}$ insults may resolve this problem. Furthermore, previous studies suggest that melatonin could maintain an optimal $\Delta \Psi_{\mathrm{m}}$ by regulating the $\mathrm{mPTP}[56,58]$. Under normal conditions, melatonin activates the $\mathrm{mPTP}$ and mildly reduces the $\Delta \Psi \mathrm{m}$. This process is associated with mitochondrial oxidative phosphorylation uncoupling [58]. Our result that $\Delta \Psi_{\mathrm{m}}$ of the group with melatonin treatment was slightly lower than the control group in both $143 \mathrm{~B}$ cells and NARP cybrids was in agreement with previous studies.

In addition, the effectiveness of melatonin in cultured NARP cybrids suggests that it might have a potentially beneficial role in the treatment of patients with mitochondrial T8993G mutation. Current treatments for such patients are rather limited. Also, as stroke-like syndrome is a common clinical presentation in inherited mitochondrial disorders [59], experiments focused on of $\mathrm{H} / \mathrm{RO}$ treatment in NARP cybrids might provide a better understanding of the pathophysiology of stroke-like syndrome in inherited mitochondrial disorder and provide the basis for potential treatment of in the future.

Several recent studies have investigated the influence of $\mathrm{H} / \mathrm{RO}$ on mitochondrial dynamics. These findings suggest that manipulating mitochondrial dynamics may provide a novel therapeutic strategy for cardioprotection. Giedt et al. suggested that $\mathrm{H} / \mathrm{RO}$ results in increased mitochondrial fission in cultured vascular endothelial cells [60]. Ong et al. showed that inhibiting mitochondrial fission with mdivi-1 protected the heart from $\mathrm{H} / \mathrm{RO}$-induced injury by preventing the opening of the mPTP [61]. Elongated mitochondria have enhanced mitochondrial respiration capacity and hyperpolarized $\Delta \Psi_{\mathrm{m}}$, which may be better equipped to withstand the metabolic stresses associated with $\mathrm{H} / \mathrm{RO}$ injury $[62,63]$.

In conclusion, NARP-induced inhibition of F1F0-ATPase significantly enhances apoptotic death and mitochondrial dysfunction in response to the H/RO insults. NARP-augmented apoptotic death upon $\mathrm{H} / \mathrm{RO}$ insults is associated with an enhanced mROS formation, which augments the depletion of cardiolipin and retards mitochondrial movement. Melatonin significantly prevents mROS-mediated depletion of cardiolipin 
and $\mathrm{mCa}^{2+}$ accumulation in NARP cybrids in response to $\mathrm{H} / \mathrm{RO}$ treatment. Melatonin improves NARP-augmented H/RO insultsinduced retardation of mitochondrial movement. $A$ better understanding of the influence of the F1F0-ATPase defect on $\mathrm{H} / \mathrm{RO}$ treatment might hold great therapeutic potential for rescuing $\mathrm{H} / \mathrm{RO}$ insults-induced cell damage and for NARPinduced pathologies and diseases. Furthermore, melatonin may potentially rescue patients with $\mathrm{H} / \mathrm{RO}$ insults (e.g. acute myocardial infarction, cerebral infarction), even in patients associated with NARP symptoms.

\section{Supporting Information}

Figure S1. Quantitative analysis of the effects of H/RO (with different hypoxia durations) on mitochondrial functions in NARP cybrids and 143B cells (Figure 3). (A) NAO (to measure cardiolipin) fluorescent intensity percentage in response to $\mathrm{H} / \mathrm{RO}(\mathrm{H}$ : $6 \mathrm{~h}, \mathrm{RO}: 2 \mathrm{~h})$ treatment in 143B cells, analyzed at $0,21,42$, and $60 \mathrm{~min}$ after the start of recording. (B) NAO fluorescent intensity percentage in response to $\mathrm{H} / \mathrm{RO}$ treatment in NARP cybrids. (C) Rhod-2 (to measure $\mathrm{mCa}^{2+}$ ) fluorescent intensity in response to $\mathrm{H} / \mathrm{RO}$ treatment in $143 \mathrm{~B}$ cells. (D) Rhod-2 fluorescent intensity in response to $\mathrm{H} / \mathrm{RO}$ treatment in NARP cybrids, ${ }^{*} P<0.05$.

(TIF)

Figure S2. Quantitative analysis of the effects of melatonin on $\Delta \Psi \mathrm{m}$ and $\mathrm{mROS}$ upon $\mathrm{H}_{2} \mathrm{O}_{2}$-augmented H/RO in 143B cells and NARP cybrids (Figure 5). (A) TMRM (to measure $\Delta \Psi \mathrm{m}$ ) fluorescent intensity in 143B cells in response to $\mathrm{H}_{2} \mathrm{O}_{2}$-augmented $\mathrm{H} / \mathrm{RO}(\mathrm{H}: 6 \mathrm{~h}, \mathrm{RO}: 2 \mathrm{~h})$ treatment, analyzed at $0,10,20$, and $30 \mathrm{~min}$ after adding $\mathrm{H}_{2} \mathrm{O}_{2}$. (B) TMRM fluorescent intensity in NARP cybrids in response to $\mathrm{H}_{2} \mathrm{O}_{2}$ augmented $\mathrm{H} / \mathrm{RO}$ treatment. (C) DCF (to measure mROS) fluorescent intensity in $143 \mathrm{~B}$ cells in response to $\mathrm{H}_{2} \mathrm{O}_{2}$ augmented $\mathrm{H} / \mathrm{RO}$ treatment. (D) DCF fluorescent intensity in NARP cybrids in response to $\mathrm{H}_{2} \mathrm{O}_{2}$-augmented $\mathrm{H} / \mathrm{RO}$ treatment.

(TIF)

Figure S3. Quantitative analysis of the effects of melatonin on cardiolipin and $\mathrm{mCa}^{2+}$ upon $\mathrm{H}_{2} \mathrm{O}_{2}$-augmented $H / R O$ in 143B cells and NARP cybrids (Figure 6). (A) NAO (to measure cardiolipin) fluorescent intensity in 143B cells in response to $\mathrm{H}_{2} \mathrm{O}_{2}$-augmented $\mathrm{H} / \mathrm{RO}(\mathrm{H}$ : $6 \mathrm{~h}, \mathrm{RO}: 2 \mathrm{~h})$ treatment, analyzed at $0,10,20$, and 30 min after adding $\mathrm{H}_{2} \mathrm{O}_{2}$. (B) NAO fluorescent intensity in NARP cybrids in response to $\mathrm{H}_{2} \mathrm{O}_{2}$ augmented $\mathrm{H} / \mathrm{RO}$ treatment. (C) Rhod-2 (to measure $\mathrm{mCa}^{2+}$ ) fluorescent intensity in $143 \mathrm{~B}$ cells in response to $\mathrm{H}_{2} \mathrm{O}_{2}$ augmented $\mathrm{H} / \mathrm{RO}$ treatment. (D) Rhod-2 fluorescent intensity in NARP cybrids in response to $\mathrm{H}_{2} \mathrm{O}_{2}$-augmented $\mathrm{H} / \mathrm{RO}$ treatment. ${ }^{*} P<0.05$.

(TIF)

Figure S4. Effects of mitochondrial specific antioxidant (MitoQ) and general antioxidant (vitamin E) on $\Delta \Psi \mathrm{m}$ and mROS upon $\mathrm{H}_{2} \mathrm{O}_{2}$-augmented $\mathrm{H} / \mathrm{RO}$ in $143 \mathrm{~B}$ cells and NARP cybrids. (A, B) Adding MitoQ $0.2 \mathrm{nM}$ or vitamin E 200 $\mu \mathrm{m}$ during $\mathrm{H}_{2} \mathrm{O}_{2}$-augmented $\mathrm{H} / \mathrm{RO}$ treatment effectively protected $\Delta \Psi_{\mathrm{m}}$ from depolarization in $143 \mathrm{~B}$ cells and NARP cybrids. (C, D) Adding MitoQ $0.2 \mathrm{nM}$ or vitamin E $200 \mu \mathrm{m}$ during $\mathrm{H}_{2} \mathrm{O}_{2}$-augmented $\mathrm{H} / \mathrm{RO}$ effectively suppressed mROS formation in 143B cells and NARP cybrids, but the effect was better in the MitoQ group. (A'-D') Quantitative analyses of A-D. $\mathrm{n}=6$. FI: fluorescence intensity. VitE : vitamin $\mathrm{E}$.

(TIF)

Figure S5. Effects of mitochondrial specific antioxidant (MitoQ) and general antioxidant (vitamin E) on cardiolipin and $\mathrm{mCa}^{2+}$ upon $\mathrm{H}_{2} \mathrm{O}_{2}$-augmented $\mathrm{H} / \mathrm{RO}$ in 143B cells and NARP cybrids. (A, B) Adding MitoQ $0.2 \mathrm{nM}$ or vitamin E 200 $\mu \mathrm{m}$ during $\mathrm{H}_{2} \mathrm{O}_{2}$-augmented $\mathrm{H} / \mathrm{RO}$ treatment effectively protected cardiolipin from depletion. (C) In 143B cells, no obvious $\mathrm{mCa}^{2+}$ accumulation was noted in response to $\mathrm{H}_{2} \mathrm{O}_{2}$ augmented $\mathrm{H} / \mathrm{RO}$. (D) Adding MitoQ $0.2 \mathrm{nM}$ or vitamin $\mathrm{E} 200$ $\mu \mathrm{m}$ during $\mathrm{H}_{2} \mathrm{O}_{2}$-augmented $\mathrm{H} / \mathrm{RO}$ effectively suppressed $\mathrm{mCa}^{2+}$ accumulation. (A'-D') Quantitative analyses of $A-D . n=6$. $\mathrm{FI}$ : fluorescence intensity. VitE : vitamin $\mathrm{E}$.

(TIF)

Figure S6. Quantitative analysis of the effects of mitochondrial specific antioxidant (MitoQ) and general antioxidant (vitamin $\mathrm{E}$ ) on $\Delta \Psi \mathrm{m}$ and $\mathrm{mROS}$ upon $\mathrm{H}_{2} \mathrm{O}_{2}$ augmented $H / R O$ in $143 B$ cells and NARP cybrids (Figure S4). (A) TMRM (to measure $\Delta \Psi \mathrm{m}$ ) fluorescent intensity in 143B cells in response to $\mathrm{H}_{2} \mathrm{O}_{2}$-augmented $\mathrm{H} / \mathrm{RO}(\mathrm{H}$ : 6h, RO: $2 \mathrm{~h})$ treatment, analyzed at $0,10,20$, and 30 min after adding $\mathrm{H}_{2} \mathrm{O}_{2}$. (B) TMRM fluorescent intensity in NARP cybrids in response to $\mathrm{H}_{2} \mathrm{O}_{2}$-augmented $\mathrm{H} / \mathrm{RO}$ treatment. (C) DCF (to measure mROS) fluorescent intensity in $143 \mathrm{~B}$ cells in response to $\mathrm{H}_{2} \mathrm{O}_{2}$ augmented $\mathrm{H} / \mathrm{RO}$ treatment. (D) DCF fluorescent intensity in NARP cybrids in response to $\mathrm{H}_{2} \mathrm{O}_{2}$-augmented $\mathrm{H} / \mathrm{RO}$ treatment. ${ }^{*} P<0.05$.

(TIF)

Figure 57. Quantitative analysis of the effects of mitochondrial specific antioxidant (MitoQ) and general antioxidant (vitamin $\mathrm{E}$ ) on cardiolipin and $\mathrm{mCa}^{2+}$ upon $\mathrm{H}_{2} \mathrm{O}_{2}$-augmented $\mathrm{H} / \mathrm{RO}$ in $143 \mathrm{~B}$ cells and NARP cybrids (Figure S5). (A) NAO (to measure cardiolipin) fluorescent intensity in 143B cells in response to $\mathrm{H}_{2} \mathrm{O}_{2}$-augmented $\mathrm{H} / \mathrm{RO}$ (H: $6 \mathrm{~h}, \mathrm{RO}: 2 \mathrm{~h}$ ) treatment, analyzed at $0,10,20$, and $30 \mathrm{~min}$ after adding $\mathrm{H}_{2} \mathrm{O}_{2}$. (B) NAO fluorescent intensity in NARP cybrids in response to $\mathrm{H}_{2} \mathrm{O}_{2}$-augmented $\mathrm{H} / \mathrm{RO}$ treatment. (C) Rhod-2 (to measure $\mathrm{mCa}^{2+}$ ) fluorescent intensity in 143B cells in response to $\mathrm{H}_{2} \mathrm{O}_{2}$-augmented $\mathrm{H} / \mathrm{RO}$ treatment. (D) Rhod-2 fluorescent intensity in NARP cybrids in response to $\mathrm{H}_{2} \mathrm{O}_{2}$ augmented $\mathrm{H} / \mathrm{RO}$ treatment. ${ }^{*} P<0.05$.

(TIF)

\section{Acknowledgements}

We are particularly grateful to Dr. Masashi Tanaka for kindly providing the NARP cybrids and 143B cell line. 


\section{Author Contributions}

Conceived and designed the experiments: WYH TIP MJJ. Performed the experiments: WYH. Analyzed the data: WYH.

\section{References}

1. Braunwald E, Kloner RA (1985) Myocardial reperfusion: a doubleedged sword? J Clin Invest 76: 1713-1719. doi:10.1172/JCI112160. PubMed: 4056048

2. Loor G, Kondapalli J, Iwase H, Chandel NS, Waypa GB et al. (2011) Mitochondrial oxidant stress triggers cell death in simulated ischemiareperfusion. Biochim Biophys Acta 1813: 1382-1394. doi:10.1016/ j.bbamcr.2010.12.008. PubMed: 21185334.

3. Abramov AY, Scorziello A, Duchen MR (2007) Three distinct mechanisms generate oxygen free radicals in neurons and contribute to cell death during anoxia and reoxygenation. J Neurosci 27: 1129-1138. doi:10.1523/JNEUROSCI.4468-06.2007. PubMed: 17267568.

4. Folbergrová J, Li PA, Uchino H, Smith ML, Siesjö BK (1997) Changes in the bioenergetic state of rat hippocampus during $2.5 \mathrm{~min}$ of ischemia, and prevention of cell damage by cyclosporin $A$ in hyperglycemic subjects. Exp Brain Res 114: 44-50. doi:10.1007/PL00005622. PubMed: 9125450

5. Katsura K, Rodriguez de Turco EB, Folbergrová J, Bazan NG, Siesjö BK (1993) Coupling among energy failure, loss of ion homeostasis, and phospholipase A2 and C activation during ischemia. J Neurochem 61: 1677-1684. doi:10.1111/j.1471-4159.1993.tb09803.x. PubMed: 8228987.

6. Liu RR, Murphy TH (2009) Reversible cyclosporin A-sensitive mitochondrial depolarization occurs within minutes of stroke onset in mouse somatosensory cortex in vivo: a two-photon imaging study. J Biol Chem 284: 36109-36117. doi:10.1074/jbc.M109.055301. PubMed: 19892710 .

7. Perrelli MG, Pagliaro P, Penna C (2011) Ischemia/reperfusion injury and cardioprotective mechanisms: Role of mitochondria and reactive oxygen species. World. J Cardiol 3: 186-200.

8. Sanderson TH, Reynolds CA, Kumar R, Przyklenk K, Hüttemann M (2013) Molecular mechanisms of ischemia-reperfusion injury in brain: pivotal role of the mitochondrial membrane potential in reactive oxygen species generation. Mol Neurobiol 47: 9-23. PubMed: 23011809.

9. Baines CP (2009) The mitochondrial permeability transition pore and ischemia-reperfusion injury. Basic Res Cardiol 104: 181-188. doi: 10.1016/j.amjcard.2009.08.522. PubMed: 19242640.

10. Griffiths EJ, Halestrap AP (1995) Mitochondrial non-specific pores remain closed during cardiac ischaemia, but open upon reperfusion. Biochem J 307 ( 1): 93-98. PubMed: 7717999.

11. Halestrap AP, Clarke SJ, Javadov SA (2004) Mitochondrial permeability transition pore opening during myocardial reperfusion--a target for cardioprotection. Cardiovasc Res 61: 372-385. doi:10.1016/ S0008-6363(03)00533-9. PubMed: 14962470.

12. Murphy E, Steenbergen C (2008) Mechanisms underlying acute protection from cardiac ischemia-reperfusion injury. Physiol Rev 88: 581-609. doi:10.1152/physrev.00024.2007. PubMed: 18391174

13. Weiss JN, Korge P, Honda HM, Ping P (2003) Role of the mitochondrial permeability transition in myocardial disease. Circ Res 93: 292-301. doi:10.1161/01.RES.0000087542.26971.D4. PubMed: 12933700 .

14. Di Lisa F, Bernardi $P$ (2009) A CaPful of mechanisms regulating the mitochondrial permeability transition. J Mol Cell Cardiol 46: 775-780. doi:10.1016/j.yjmcc.2009.03.006. PubMed: 19303419.

15. Di Lisa F, Canton M, Carpi A, Kaludercic N, Menabò R et al. (2011) Mitochondrial injury and protection in ischemic pre- and postconditioning. Antioxid Redox Signal 14: 881-891. doi:10.1089/ars. 2010.3375. PubMed: 20615074

16. Heusch G, Boengler K, Schulz R (2010) Inhibition of mitochondrial permeability transition pore opening: the Holy Grail of cardioprotection. Basic Res Cardiol 105: 151-154. doi:10.1007/s00395-009-0080-9. PubMed: 20066536.

17. Ruiz-Meana M, Abellán A, Miró-Casas E, Garcia-Dorado D (2007) Opening of mitochondrial permeability transition pore induces hypercontracture in $\mathrm{Ca} 2+$ overloaded cardiac myocytes. Basic Res Cardiol 102: 542-552. doi:10.1007/s00395-007-0675-y. PubMed: 17891523.

18. Ambrosio G, Zweier JL, Duilio C, Kuppusamy P, Santoro G et al. (1993) Evidence that mitochondrial respiration is a source of potentially
Contributed reagents/materials/analysis tools: WYH TIP MJJ. Wrote the manuscript: WYH TIP.

toxic oxygen free radicals in intact rabbit hearts subjected to ischemia and reflow. J Biol Chem 268: 18532-18541. PubMed: 8395507.

19. Bolli R, Marbán E (1999) Molecular and cellular mechanisms of myocardial stunning. Physiol Rev 79: 609-634. PubMed: 10221990.

20. Baracca A, Barogi S, Carelli V, Lenaz G, Solaini G (2000) Catalytic activities of mitochondrial ATP synthase in patients with mitochondrial DNA T8993G mutation in the ATPase 6 gene encoding subunit a. J Biol Chem 275: 4177-4182. doi:10.1074/jbc.275.6.4177. PubMed: 10660580.

21. Peng TI, Hsiao CW, Reiter RJ, Tanaka M, Lai YK et al. (2012) mtDNA T8993G mutation-induced mitochondrial complex $V$ inhibition augments cardiolipin-dependent alterations in mitochondrial dynamics during oxidative, $\mathrm{Ca}(2+)$, and lipid insults in NARP cybrids: a potential therapeutic target for melatonin. J Pineal Res 52: 93-106. doi:10.1111/j. 1600-079X.2011.00923.x. PubMed: 21812817.

22. Geromel V, Kadhom N, Cebalos-Picot I, Ouari O, Polidori A et al. (2001) Superoxide-induced massive apoptosis in cultured skin fibroblasts harboring the neurogenic ataxia retinitis pigmentosa (NARP) mutation in the ATPase- 6 gene of the mitochondrial DNA. Hum Mol Genet 10: 1221-1228. doi:10.1093/hmg/10.11.1221. PubMed: 11371515

23. Kaneko S, Okumura K, Numaguchi Y, Matsui H, Murase K et al. (2000) Melatonin scavenges hydroxyl radical and protects isolated rat hearts from ischemic reperfusion injury. Life Sci 67: 101-112. doi:10.1016/ S0024-3205(00)00607-X. PubMed: 10901278.

24. Reiter RJ, Tan DX (2003) Melatonin: a novel protective agent against oxidative injury of the ischemic/reperfused heart. Cardiovasc Res 58: 10-19. doi:10.1016/S0008-6363(02)00827-1. PubMed: 12667942.

25. Salie R, Harper I, Cillie C, Genade S, Huisamen B et al. (2001) Melatonin protects against ischaemic-reperfusion myocardial damage. J Mol Cell Cardiol 33: 343-357. doi:10.1006/jmcc.2000.1306. PubMed: 11162138.

26. Tan DX, Manchester LC, Reiter RJ, Qi W, Kim SJ et al. (1998) Ischemia/reperfusion-induced arrhythmias in the isolated rat heart: prevention by melatonin. J Pineal Res 25: 184-191. doi:10.1111/j. 1600-079X.1998.tb00558.x. PubMed: 9745988.

27. Tengattini S, Reiter RJ, Tan DX, Terron MP, Rodella LF et al. (2008) Cardiovascular diseases: protective effects of melatonin. J Pineal Res 44: 16-25. PubMed: 18078444.

28. Kilic E, Kilic U, Reiter RJ, Bassetti CL, Hermann DM (2005) Tissueplasminogen activator-induced ischemic brain injury is reversed by melatonin: role of iNOS and Akt. J Pineal Res 39: 151-155. doi: 10.1111/j.1600-079X.2005.00228.x. PubMed: 16098092.

29. Kilic E, Kilic U, Yulug B, Hermann DM, Reiter RJ (2004) Melatonin reduces disseminate neuronal death after mild focal ischemia in mice via inhibition of caspase- 3 and is suitable as an add-on treatment to tissue-plasminogen activator. J Pineal Res 36: 171-176. doi:10.1046/j. 1600-079X.2003.00115.x. PubMed: 15009507

30. Tanaka M, Borgeld HJ, Zhang J, Muramatsu S, Gong JS et al. (2002) Gene therapy for mitochondrial disease by delivering restriction endonuclease Smal into mitochondria. J Biomed Sci 9: 534-541. doi: 10.1159/000064726. PubMed: 12372991.

31. Mosmann T (1983) Rapid colorimetric assay for cellular growth and survival: application to proliferation and cytotoxicity assays. J Immunol Methods 65: 55-63. doi:10.1016/0022-1759(83)90303-4. PubMed: 6606682.

32. Strober W (2001) Trypan blue exclusion test of cell viability. Curr Protoc Immunol Appendix 3: Appendix 3B

33. van Engeland $M$, Nieland LJ, Ramaekers FC, Schutte $B$ Reutelingsperger CP (1998) Annexin V-affinity assay: a review on an apoptosis detection system based on phosphatidylserine exposure. Cytometry 31: 1-9. doi:10.1002/(SICI)1097-0320(19980101)31:1. PubMed: 9450519.

34. Baracca A, Sgarbi G, Mattiazzi M, Casalena G, Pagnotta E et al. (2007) Biochemical phenotypes associated with the mitochondrial ATP6 gene mutations at nt8993. Biochim Biophys Acta 1767: 913-919. doi: 10.1016/j.bbabio.2007.05.005. PubMed: 17568559 .

35. Lebiedzinska M, Karkucinska-Wieckowska A, Wojtala A, Suski JM, Szabadkai G et al. (2013) Disrupted ATP synthase activity and mitochondrial hyperpolarisation-dependent oxidative stress is 
associated with p66Shc phosphorylation in fibroblasts of NARP patients. Int J Biochem Cell Biol 45: 141-150. doi:10.1016/j.biocel. 2012.07.020. PubMed: 22885148

36. Huang WY, Weng WC, Peng TI, Chien YY, Wu CL et al. (2012) Association of hyponatremia in acute stroke stage with three-year mortality in patients with first-ever ischemic stroke. Cerebrovasc Dis 34: 55-62. doi:10.1159/000338906. PubMed: 22759703.

37. Jou MJ, Peng TI, Yu PZ, Jou SB, Reiter RJ et al. (2007) Melatonin protects against common deletion of mitochondrial DNA-augmented mitochondrial oxidative stress and apoptosis. J Pineal Res 43: 389-403. doi:10.1111/j.1600-079X.2007.00490.x. PubMed: 17910608.

38. Peng TI, Yu PR, Chen JY, Wang HL, Wu HY et al. (2006) Visualizing common deletion of mitochondrial DNA-augmented mitochondrial reactive oxygen species generation and apoptosis upon oxidative stress. Biochim Biophys Acta 1762: 241-255. doi:10.1016/j.bbadis. 2005.10.008. PubMed: 16368227.

39. Mattiazzi M, Vijayvergiya C, Gajewski CD, DeVivo DC, Lenaz G et al. (2004) The mtDNA T8993G (NARP) mutation results in an impairment of oxidative phosphorylation that can be improved by antioxidants. Hum Mol Genet 13: 869-879. doi:10.1093/hmg/ddh103. PubMed: 14998933.

40. Lesnefsky EJ, Chen Q, Slabe TJ, Stoll MS, Minkler PE et al. (2004) Ischemia, rather than reperfusion, inhibits respiration through cytochrome oxidase in the isolated, perfused rabbit heart: role of cardiolipin. Am J Physiol Heart Circ Physiol 287: H258-H267. doi: 10.1152/ajpheart.00348.2003. PubMed: 14988071.

41. Paradies G, Petrosillo G, Pistolese M, Di Venosa N, Serena D et al. (1999) Lipid peroxidation and alterations to oxidative metabolism in mitochondria isolated from rat heart subjected to ischemia and reperfusion. Free Radic Biol Med 27: 42-50. doi:10.1016/ S0891-5849(99)90636-6. PubMed: 10443918.

42. Petrosillo G, Ruggiero FM, Di Venosa N, Paradies G (2003) Decreased complex III activity in mitochondria isolated from rat heart subjected to ischemia and reperfusion: role of reactive oxygen species and cardiolipin. FASEB J 17: 714-716. PubMed: 12586737.

43. Paradies G, Petrosillo G, Pistolese M, Di Venosa N, Federici A et al. (2004) Decrease in mitochondrial complex I activity in ischemic/ reperfused rat heart: involvement of reactive oxygen species and cardiolipin. Circ Res 94: 53-59. doi:10.1161/01.RES 0000109416.56608.64. PubMed: 14656928.

44. Petrosillo G, Casanova G, Matera M, Ruggiero FM, Paradies G (2006) Interaction of peroxidized cardiolipin with rat-heart mitochondrial membranes: induction of permeability transition and cytochrome c release. FEBS Lett 580: 6311-6316. doi:10.1016/j.febslet.2006.10.036. PubMed: 17083938.

45. Petrosillo G, Moro N, Ruggiero FM, Paradies G (2009) Melatonin inhibits cardiolipin peroxidation in mitochondria and prevents the mitochondrial permeability transition and cytochrome $c$ release. Free Radic Biol Med 47: 969-974. doi:10.1016/j.freeradbiomed.2009.06.032. PubMed: 19577639.

46. Venegas C, García JA, Escames G, Ortiz F, López A et al. (2012) Extrapineal melatonin: analysis of its subcellular distribution and daily fluctuations. J Pineal Res 52: 217-227. doi:10.1111/j.1600-079X. 2011.00931.x. PubMed: 21884551.

47. Rosen J, Than NN, Koch D, Poeggeler B, Laatsch H et al. (2006) Interactions of melatonin and its metabolites with the ABTS cation radical: extension of the radical scavenger cascade and formation of a novel class of oxidation products, C2-substituted 3-indolinones. J Pineal Res 41: 374-381. doi:10.1111/j.1600-079X.2006.00379.x. PubMed: 17014695.

48. Tan DX, Manchester LC, Reiter RJ, Qi WB, Karbownik M et al. (2000) Significance of melatonin in antioxidative defense system: reactions and products. Biol Signals Recept 9: 137-159. doi:10.1159/000014635. PubMed: 10899700

49. Tan DX, Manchester LC, Terron MP, Flores LJ, Reiter RJ (2007) One molecule, many derivatives: a never-ending interaction of melatonin with reactive oxygen and nitrogen species? J Pineal Res 42: 28-42. doi: 10.1111/j.1600-079X.2006.00407.x. PubMed: 17198536.

50. Galano A, Tan DX, Reiter RJ (2011) Melatonin as a natural ally against oxidative stress: a physicochemical examination. J Pineal Res 51: 1-16. doi:10.1111/j.1600-079X.2011.00916.x. PubMed: 21752095.

51. Galano A, Tan DX, Reiter RJ (2013) On the free radical scavenging activities of melatonin's metabolites, AFMK and AMK. J Pineal Res 54: 245-257. doi:10.1111/jpi.12010. PubMed: 22998574.

52. Rodriguez C, Mayo JC, Sainz RM, Antolín I, Herrera F et al. (2004) Regulation of antioxidant enzymes: a significant role for melatonin. J Pineal Res 36: 1-9. doi:10.1046/j.1600-079X.2003.00092.x. PubMed: 14675124.

53. Drew JE, Barrett P, Mercer JG, Moar KM, Canet E et al. (2001) Localization of the melatonin-related receptor in the rodent brain and peripheral tissues. J Neuroendocrinol 13: 453-458. doi:10.1046/j. 1365-2826.2001.00651.x. PubMed: 11328456

54. Wang X, Sirianni A, Pei Z, Cormier K, Smith K et al. (2011) The melatonin MT1 receptor axis modulates mutant Huntingtin-mediated toxicity. J Neurosci 31: 14496-14507. doi:10.1523/JNEUROSCI. 3059-11.2011. PubMed: 21994366.

55. Peyrot F, Ducrocq C (2008) Potential role of tryptophan derivatives in stress responses characterized by the generation of reactive oxygen and nitrogen species. J Pineal Res 45: 235-246. doi:10.1111/j. 1600-079X.2008.00580.x. PubMed: 18341517.

56. Andrabi SA, Sayeed I, Siemen D, Wolf G, Horn TF (2004) Direct inhibition of the mitochondrial permeability transition pore: a possible mechanism responsible for anti-apoptotic effects of melatonin. FASEB J 18: 869-871. PubMed: 15033929.

57. Petrosillo G, Colantuono G, Moro N, Ruggiero FM, Tiravanti E et al. (2009) Melatonin protects against heart ischemia-reperfusion injury by inhibiting mitochondrial permeability transition pore opening. Am J Physiol Heart Circ Physiol 297: H1487-H1493. doi:10.1152/ajpheart. 00163.2009. PubMed: 19684190.

58. Tan DX, Manchester LC, Liu X, Rosales-Corral SA, Acuna-Castroviejo D et al. (2013) Mitochondria and chloroplasts as the original sites of melatonin synthesis: a hypothesis related to melatonin's primary function and evolution in eukaryotes. J Pineal Res 54: 127-138. doi: 10.1111/jpi.12026. PubMed: 23137057.

59. Finsterer J (2012) Inherited mitochondrial disorders. Adv Exp Med Biol 942: 187-213. doi:10.1007/978-94-007-2869-1_8. PubMed: 22399423.

60. Giedt RJ, Yang C, Zweier JL, Matzavinos A, Alevriadou BR (2012) Mitochondrial fission in endothelial cells after simulated ischemia/ reperfusion: role of nitric oxide and reactive oxygen species. Free Radic Biol Med 52: 348-356. doi:10.1016/j.freeradbiomed.2011.10.491. PubMed: 22100972

61. Ong SB, Subrayan S, Lim SY, Yellon DM, Davidson SM et al. (2010) Inhibiting mitochondrial fission protects the heart against ischemia/ reperfusion injury. Circulation 121: 2012-2022. doi:10.1161/ CIRCULATIONAHA.109.906610. PubMed: 20421521.

62. Chen H, Chomyn A, Chan DC (2005) Disruption of fusion results in mitochondrial heterogeneity and dysfunction. J Biol Chem 280: 26185-26192. doi:10.1074/jbc.M503062200. PubMed: 15899901.

63. Ong SB, Hausenloy DJ (2010) Mitochondrial morphology and cardiovascular disease. Cardiovasc Res 88: 16-29. doi:10.1093/cvr/ cvq237. PubMed: 20631158. 